University of Vermont

UVM ScholarWorks

$5-1-2017$

\title{
Tropical river suspended sediment and solute dynamics in storms during an extreme drought
}

\author{
Kathryn E. Clark \\ University of Pennsylvania \\ James B. Shanley \\ United States Geological Survey \\ Martha A. Scholl \\ United States Geological Survey \\ Nicolas Perdrial \\ University of Vermont \\ Julia N. Perdrial \\ University of Vermont
}

See next page for additional authors

Follow this and additional works at: https://scholarworks.uvm.edu/casfac

Part of the Climate Commons

\section{Recommended Citation}

Clark KE, Shanley JB, Scholl MA, Perdrial N, Perdrial JN, Plante AF, McDowell WH. Tropical river suspended sediment and solute dynamics in storms during an extreme drought. Water Resources Research. 2017 May;53(5):3695-712.

This Article is brought to you for free and open access by the College of Arts and Sciences at UVM ScholarWorks. It has been accepted for inclusion in College of Arts and Sciences Faculty Publications by an authorized administrator of UVM ScholarWorks. For more information, please contact scholarworks@uvm.edu. 
Authors

Kathryn E. Clark, James B. Shanley, Martha A. Scholl, Nicolas Perdrial, Julia N. Perdrial, Alain F. Plante, and William H. McDowell 


\section{Water Resources Research}

\section{RESEARCH ARTICLE \\ 10.1002/2016WR019737 \\ Tropical river suspended sediment and solute dynamics in storms during an extreme drought}

Special Section:

Concentration-discharge

Relations in the Critical Zone

\section{Key Points:}

- Concentration-discharge relations for solutes and suspended sediment in four storms during extreme drought mostly conformed to long-term patterns

- Rainfall intensity and surface flow paths controlled sediment movement to the river during the drought rewetting response

- During the drought rewetting events, the source of suspended sediment was initially the channel, then progressively shifted to catchment soils

Supporting Information: - Supporting Information S1

Correspondence to:

K. E. Clark,

kathryn.clark23@gmail.com

Citation:

Clark, K. E., J. B. Shanley, M. A. Scholl, N. Perdrial, J. N. Perdrial, A. F. Plante, and W. H. McDowell (2017), Tropical river suspended sediment and solute dynamics in storms during an extreme drought, Water Resour. Res., 53, 36953712, doi:10.1002/2016WR019737.

Received 31 AUG 2016 Accepted 4 MAR 2017 Accepted article online 9 MAR 2017 Published online 3 MAY 2017

(c) 2017. American Geophysical Union. All Rights Reserved.

\author{
Kathryn E. Clark ${ }^{1}$ (D) James B. Shanley ${ }^{2}$, Martha A. Scholl ${ }^{3}$ (D) Nicolas Perdrial ${ }^{4}$, Julia N. Perdrial ${ }^{4}$ (i), \\ Alain F. Plante ${ }^{1}$ (D), and William H. McDowell5 (D) \\ ${ }^{1}$ Department of Earth and Environmental Science, University of Pennsylvania, Philadelphia, Pennsylvania, USA, ${ }^{2}$ United \\ States Geological Survey, New England Water Science Center, Montpelier, Vermont, USA, ${ }^{3}$ United States Geological \\ Survey, National Research Program, Reston, Virginia, USA, ${ }^{4}$ Department of Geology, University of Vermont, Burlington, \\ Vermont, USA, ${ }^{5}$ Department of Natural Resources and the Environment, University of New Hampshire, Durham, New \\ Hampshire, USA
}

\begin{abstract}
Droughts, which can strongly affect both hydrologic and biogeochemical systems, are projected to become more prevalent in the tropics in the future. We assessed the effects of an extreme drought during 2015 on stream water composition in the Luquillo Mountains of Puerto Rico. We demonstrated that drought base flow in the months leading up to the study was sourced from trade-wind orographic rainfall, suggesting a resistance to the effects of an otherwise extreme drought. In two catchments (Mameyes and Icacos), we sampled a series of four rewetting events that partially alleviated the drought. We collected and analyzed dissolved constituents (major cations and anions, organic carbon, and nitrogen) and suspended sediment (inorganic and organic matter (particulate organic carbon and particulate nitrogen)). The rivers appeared to be resistant to extreme drought, recovering quickly upon rewetting, as (1) the concentration-discharge (C-Q) relationships deviated little from the long-term patterns; (2) "new water" dominated streamflow during the latter events; (3) suspended sediment sources had accumulated in the channel during the drought flushed out during the initial events; and (4) the severity of the drought, as measured by the US drought monitor, was reduced dramatically after the rewetting events. Through this interdisciplinary study, we were able to investigate the impact of extreme drought through rewetting events on the river biogeochemistry.
\end{abstract}

\section{Introduction}

Tropical ecosystems are a major contributor to global carbon and nutrient cycles [Lal et al., 2000; Schlesinger and Bernhardt, 2013], contributing one-third of the total metabolic activity of the Earth's land surface [Malhi, 2012]. Tropical rivers play a vital role carrying sediment and solutes to the world's oceans [Stallard and Edmond, 1983; Gaillardet et al., 1999; Milliman and Farnsworth, 2011]. Physical and chemical weathering that occurs in tropical montane systems is an important driver of these yields [Gibbs, 1967; Milliman and Meade, 1983], with disturbances such as hurricanes and landslides playing an important role [Scatena and Larsen, 1991; Larsen and Simon, 1993; Larsen, 2012; Clark et al., 2016].

An intermediate level of disturbance to a system can be beneficial, producing greater diversity [Connell, 1978], with extreme climatic events promoting a natural and important source of variability in rivers [Ledger and Milner, 2015]. Future projected climatic extremes may impact the resiliency of stream ecosystems [Ormerod, 2009]. In the future, the Caribbean is expected to become drier [IPCC, 2013], with stronger but less frequent cyclonic storms [IPCC, 2013; GFDL, 2016]. Thus, it is important to evaluate the resilience and/or resistance of river systems to extreme climate events [Smith, 2011], as they can induce shifts in ecosystem structure. The terms resilience and resistance are traditionally applied to describe the ecological responses to disturbance [MacGillivray et al., 1995]. For the purposes of this paper, however, we define resistance as the ability of river to undergo disturbance (storms or droughts) with minimal effect on biogeochemical dynamics, e.g., solute and particulate $\mathrm{C}-\mathrm{Q}$ relations. We define resilience as the ability of river biogeochemistry to recover quickly following disturbance.

A fortuitous set of circumstances presented an opportunity to examine the resistance of river biogeochemistry during several rewetting events during the extreme drought of 2015 in the Luquillo Critical Zone 


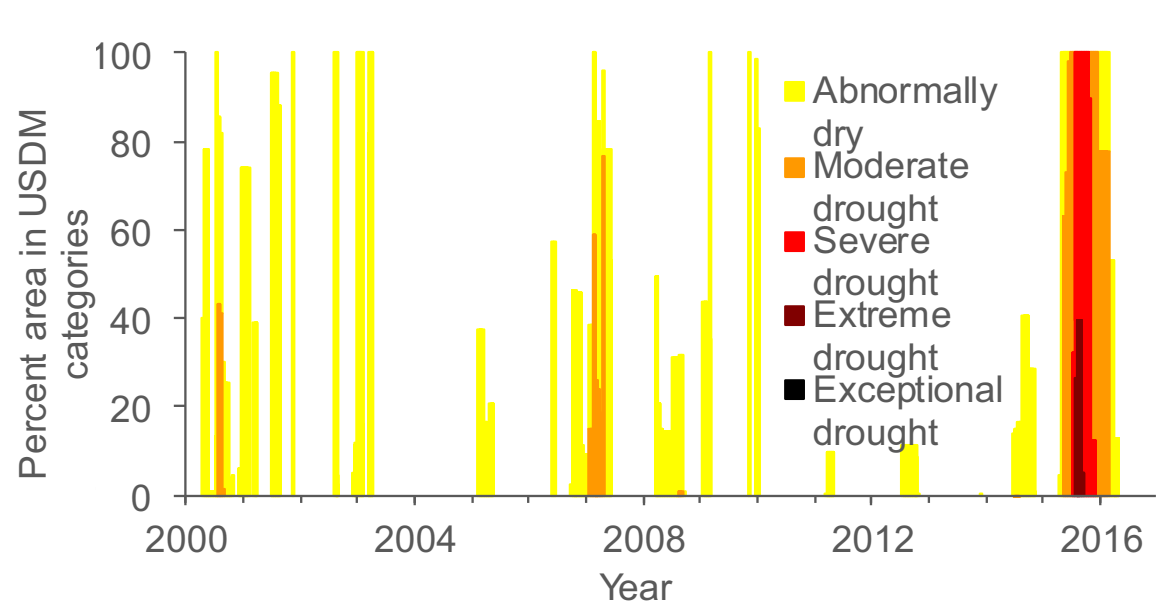

Figure 1. U.S. drought monitor (USDM) record for the region encompassing the Mameyes (MPR) and Icacos (RI) catchments, with the averaged values of weekly percent area within each category of the USDM for the municipalities of Río Grande, Luquillo, and Naguabo from 2000 to 2016 [USDM, 2017].

Observatory (LCZO). We define rewetting as a rainfall event that occurs within a drought that produces a discharge peak with a magnitude greater than any that had been recorded in the preceding 3 months. In late August 2015, in the midst of the largest and longest drought in 20 years (Figure 1) [USGS, 2016c], two cyclones approached Puerto Rico [NOAA, 2016]. Prevailing dry air and wind shear resulted in their demise, first with the collapse of Hurricane Danny and second with the weakening of Tropical Storm Erika (Table 1) [NOAA, 2015]. However, remnants of these storms produced a series of rewetting events during an 8 day period at the peak of the drought (Figure 1). We intensively sampled two LCZO streams, Río Mameyes at Puente Roto (MPR) and Río Icacos (RI), to assess the impact of the drought on river biogeochemistry through this series of rewetting events.

To monitor the river biogeochemistry during rewetting events, we evaluated water, solutes, and suspended sediment (particulate) chemistry. Under drought conditions, we might expect rainfall from the rewetting events to first satisfy the large soil moisture deficits; any recharge should displace pre-event groundwater into the stream, and the fraction of "new water" should be low. Additionally, we would expect solutes to build up, so that subsequent rainfall would activate flow paths and flush accumulated solutes into the river as has been observed in other systems [Huntington et al., 1994; Burt et al., 2015]. Furthermore, a lack of surface runoff pathways would limit flushing of soil-derived material from the catchment into the streams and we would hence expect in-channel sediment to dominate river particulate load.

To evaluate the river biogeochemical response, we compared concentration-discharge (C-Q) relationships during the events to the long-term C-Q patterns. The relationship between $\mathrm{C}$ and $\mathrm{Q}$ in a given stream is the result of a specific yet complex coupling between hydrological and biogeochemical processes [Walling and

\begin{tabular}{|c|c|c|c|c|c|c|c|c|c|}
\hline $\begin{array}{l}\text { Start and End } \\
\text { Rainfall } \\
\text { (dd/m/yy hh) }\end{array}$ & $\begin{array}{l}\text { Rain Event } \\
\text { Number }\end{array}$ & $\begin{array}{c}\text { Total } \\
\text { (Peak Hour) } \\
\text { Rainfall } \\
\text { RI }(\mathrm{mm})\end{array}$ & $\begin{array}{c}\text { Total } \\
\text { (Peak Hour) } \\
\text { Rainfall } \\
\text { MPR }(\mathrm{mm})\end{array}$ & $\begin{array}{l}\text { Lag in } \\
\text { Runoff } \\
\text { (Hours) }\end{array}$ & $\begin{array}{c}\text { Total } \\
\text { (Peak Hour) } \\
\text { Runoff } \\
\text { RI (mm) }\end{array}$ & $\begin{array}{c}\text { Total } \\
\text { (Peak Hour) } \\
\text { Runoff MPR } \\
(\mathrm{mm})\end{array}$ & $\begin{array}{l}\text { RI Runoff } \\
\text { Ratio }\end{array}$ & $\begin{array}{l}\text { MPR Runoff } \\
\quad \text { Ratio }\end{array}$ & Source Weather \\
\hline 24/8/15 23-25/8/15 14 & 1 & $53.1(14.0)$ & $13.5(3.0)$ & 7 & $10.5(3.5)$ & $5.8(1.3)$ & 0.20 & 0.43 & Remnants of Hurricane Danny \\
\hline 27/8/15 00-27/8/15 12 & 2 & $36.6(11.0)$ & $20.7(7.8)$ & 6 & $10.7(2.5)$ & $7.9(1.7)$ & 0.29 & 0.38 & Precipitation associated with Tropical Storm Erika \\
\hline 27/8/15 15-28/8/15 11 & 3 & $70.6(9.1)$ & $28.5(8.4)$ & 7 & $35.9(9.9)$ & $41.5(11.8)$ & 0.51 & 1.46 & $\begin{array}{l}\text { Thunderstorms trailing cancelled } \\
\text { Tropical Storm Erika }\end{array}$ \\
\hline 01/9/15 17-02/9/15 03 & 4 & $53.3(41.9)$ & $42.7(32.5)$ & 1 & $18.7(6.2)$ & $24.6(9.3)$ & 0.35 & 0.58 & Tropical wave \\
\hline
\end{tabular}

Note: The duration of the event hydrograph varied between the catchments.

MPR, Mameyes Puente Roto; RI, Rio Icacos. Rainfall for MPR was recorded at the Sabana field station, 3 km east of MPR gage, and may not reflect actual rainfall in MPR watershed. 
Webb, 1986; Evans and Davies, 1998; Godsey et al., 2009]. We explore the composition of streamflow during drought and rewetting to determine its source, which has been shown in past work to contain 20-50\% "new water" over the storm hydrograph [Schellekens et al., 2004; Scholl et al., 2015]. We explore the composition of suspended particulates in the $\mathrm{C}-\mathrm{Q}$ context during rewetting, to determine sediment sources and hysteresis patterns [Hilton et al., 2008; Clark et al., 2013; Gellis, 2013; Inamdar et al., 2015].

\section{Study Area}

Puerto Rico is a small Caribbean island $\left(9000 \mathrm{~km}^{2}\right)$ in the Greater Antilles (Figure 2). The two study catchments are in the El Yunque National Forest in northeastern Puerto Rico, and are part of the Luquillo Critical Zone Observatory (LCZO). The Mameyes River at Puente Roto (MPR) is $16.6 \mathrm{~km}$ long with a catchment area of $17.8 \mathrm{~km}^{2}$ and an elevation range of 83-1050 masl. The MPR gage is upstream of the coastal plain segment of the Mameyes River, which flows an additional $7.4 \mathrm{~km}$ north before discharging to the Atlantic Ocean (Figure 2) [Larsen, 1997; Murphy et al., 2012]. The Rio Icacos (RI) is $2.0 \mathrm{~km}$ long with a catchment area of $3.26 \mathrm{~km}^{2}$ and an elevation range of 620-832 masl. Rl flows an additional $0.9 \mathrm{~km}$ to the Rio Blanco, which discharges to the Caribbean Sea (Figure 2) [Larsen, 1997; Murphy et al., 2012].

Mean annual rainfall in the Luquillo Mountains is $\sim 4400 \mathrm{~mm}$, with the highest rainfall at highest elevations [Murphy and Stallard, 2012]. The Caribbean has a bimodal rainy season, with the early wet season May to July and the late wet season August through October [Taylor et al., 2002]. The wetter months are characterized by convective rainfall including tropical easterly waves, low-pressure troughs and tropical storms/hurricanes. Trade-wind orographic showers occur year-round, but predominate in the mountains in the drier winter months, with other rainfall coming from low-pressure troughs and cold fronts [Scholl et al., 2009; Scholl and Murphy, 2014]. The warm and wet climate supports productive forests in the mountains. The MPR catchment has lower montane rain forest, subtropical rain forest, and subtropical wet forest. The RI catchment is dominated by lower montane wet forest [Murphy et al., 2012].

Stream runoff has been monitored by the USGS since 1945 at RI and since 1967 at MPR. From 1991 to 2005, the mean annual runoff was $3760 \mathrm{~mm}$ at RI and $2750 \mathrm{~mm}$ at MPR [Murphy and Stallard, 2012]. There has been a substantial amount of research carried out on the suspended and dissolved river chemistry of the

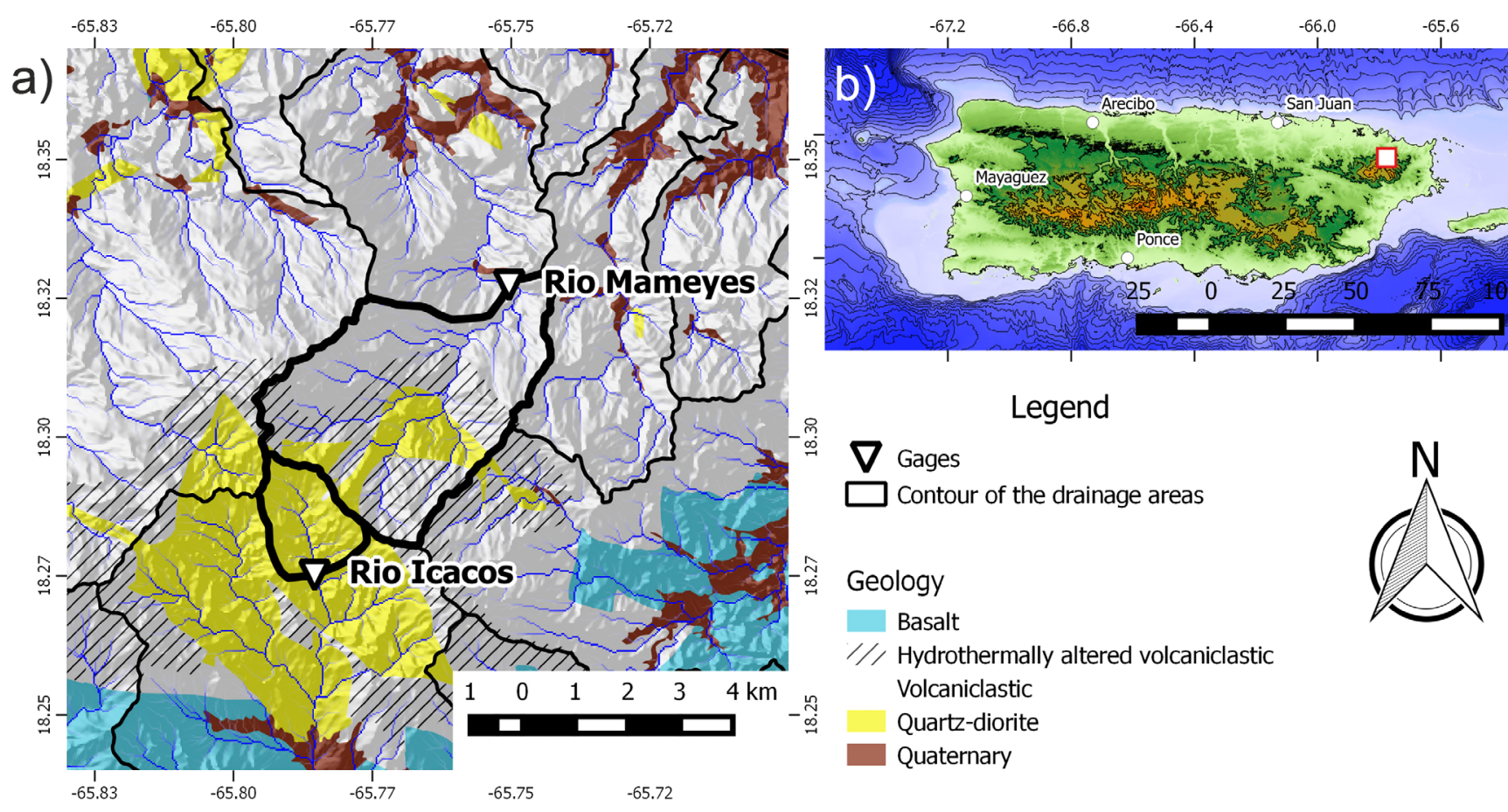

Figure 2. (a) Geologic map of the two study catchments. Mameyes Puente Roto (MPR) has three geological formations, volcaniclastic, a modified volcaniclastic, and quartz diorite. Rio Icacos (RI) has one geological unit, quartz diorite. (b) The island of Puerto Rico with the study area within the box [Seiders, 1971; Bawiec, 1999]. 
Luquillo Mountains, by the LCZO and Luquillo Long Term Ecological Research (LUQ LTER) [McDowell and Asbury, 1994], and the U.S. Geological Survey Water, Energy, and Biogeochemical Budgets (WEBB) project in Luquillo [Shanley et al., 2011; Stallard, 2012; Stallard and Murphy, 2012].

Puerto Rico is mainly comprised of an old uplifted shore platform of volcanic rock [Brocard et al., 2015]. The Luquillo Mountains have a steep topography, with a mean slope of $\sim 13^{\circ}$ for the RI catchment and $\sim 21^{\circ}$ for the MPR catchment [Larsen, 1997], which influences river dynamics [White et al., 1998; Porder et al., 2015]. The bedrock of the RI watershed consists almost exclusively (99\%) of the paleogene quartzdiorite (Figure 2a) [Smith et al., 1998] producing saprolite that is principally composed of quartz, weathered mica, kaolinite, and other clays [Murphy et al., 2012] covered by $0.5-2 \mathrm{~m}$ of sandy inceptisol soil [Simon et al., 1990]. Fine to medium sand dominates the bed sediment in the low-gradient RI channel, with a median grain size of $0.6 \mathrm{~mm}$ [Larsen, 1997]. The bedrock of the MPR watershed is more heterogeneous, consisting of $82 \%$ cretaceous volcaniclastic rocks and $18 \%$ Rio Blanco quartz diorite [Murphy et al., 2012]. Saprolite forming from this bedrock is rich in kaolinite, iron and aluminum oxides, and small amounts of quartz [Murphy et al., 2012]. Soils overlying the catchment are typically clay-rich and quartzpoor, ranging from high-elevation inceptisols to low-elevation oxisols. The MPR streambed is dominated by cobbles and boulders, with minimal fines, and a median grain size of $125 \mathrm{~mm}$ [Phillips and Jerolmack, 2016].

\section{Materials and Methods}

\subsection{Hydrometric Measurements}

Rainfall was measured at 15 min intervals with an OTT Pluvio weighing rain gage near the MPR gage at Sabana Forest Service field station just outside the MPR catchment (Figure 3a and Table 1). Rainfall at RI was measured at 5-15 min intervals with a tipping bucket rain gage, measured near the stream gage (Figure $3 \mathrm{a}$ and Table 1) [USGS, 2016b]. Discharge for both streams was determined from stage measurements at USGS real-time stream gages [USGS, 2016a, 2016b]. River stage height was recorded at 15 min intervals (5 min intervals during events) and converted to discharge from empirical stage-discharge rating curves at each site [USGS, 2016a, 2016b]. Additionally, RI had a sensor package deployed just upstream of the gage. Measurements included turbidity (Turner Designs C7; resolution $\pm 0.1 \mathrm{FNU}$ ), and a water temperature thermistor and specific conductance cell in an integrated sensor (Campbell Scientific C547) recorded at 515 min intervals. Specific conductance measurements of stream water and a single rainfall sample (from the PR20 NADP site) allowed us to perform a two-component hydrograph separation based on conductance for Event 4 at RI.

\subsection{Water Sample Collection and Processing}

At the MPR gage, stream water for stable isotope determination was sampled weekly from March 2010 to September 2016. Stream samples were also collected at MPR and RI during Event 3. Isotope samples were stored in $60 \mathrm{~mL}$ glass bottles with conical-insert caps and shipped to the USGS Stable Isotope Laboratory in Reston, VA.

Stream water for particulate load and dissolved load was collected between 22 August and 1 September 2015 from the gaging stations at both sites, during four rewetting events and intervening base flow (Figure 3). Using a combination of manual and automatic sampling, 22 samples were collected at RI and 33 samples were collected at MPR. At RI, samples were collected by an automatic water sampler (ICSO 3700) for three rewetting events. The ISCO was triggered at a runoff of $2.0 \mathrm{~mm} \mathrm{~h}^{-1}$ and sampled hourly until stage returned to the threshold value. Manual grab samples of stream water were taken at MPR, where sampling was limited to daylight hours for safety reasons. This led to poorer coverage of peak events at MPR, with samples only capturing peak discharge during one event (Event 2). For the large rainfall Event 3, streamflow sampling at MPR commenced well into the falling limb, and Event 4 was not sampled at all. River water samples were collected within the water column at the side of the channel, in DI-rinsed (>18.2 m $\Omega$ ) 1-L ISCO polyethylene (HDEI) bottles. Base flow grab samples were taken before and after the rewetting events. Most stream water samples were $\sim 1 \mathrm{~L}$, with some larger samples of $\sim 18 \mathrm{~L}$ to enable SS quantification at low flow. The samples are likely to be representative of the mean channel particulate load due to large scale bed roughness, which promotes thorough mixing of the river water [Lupker et al., 2011]. 

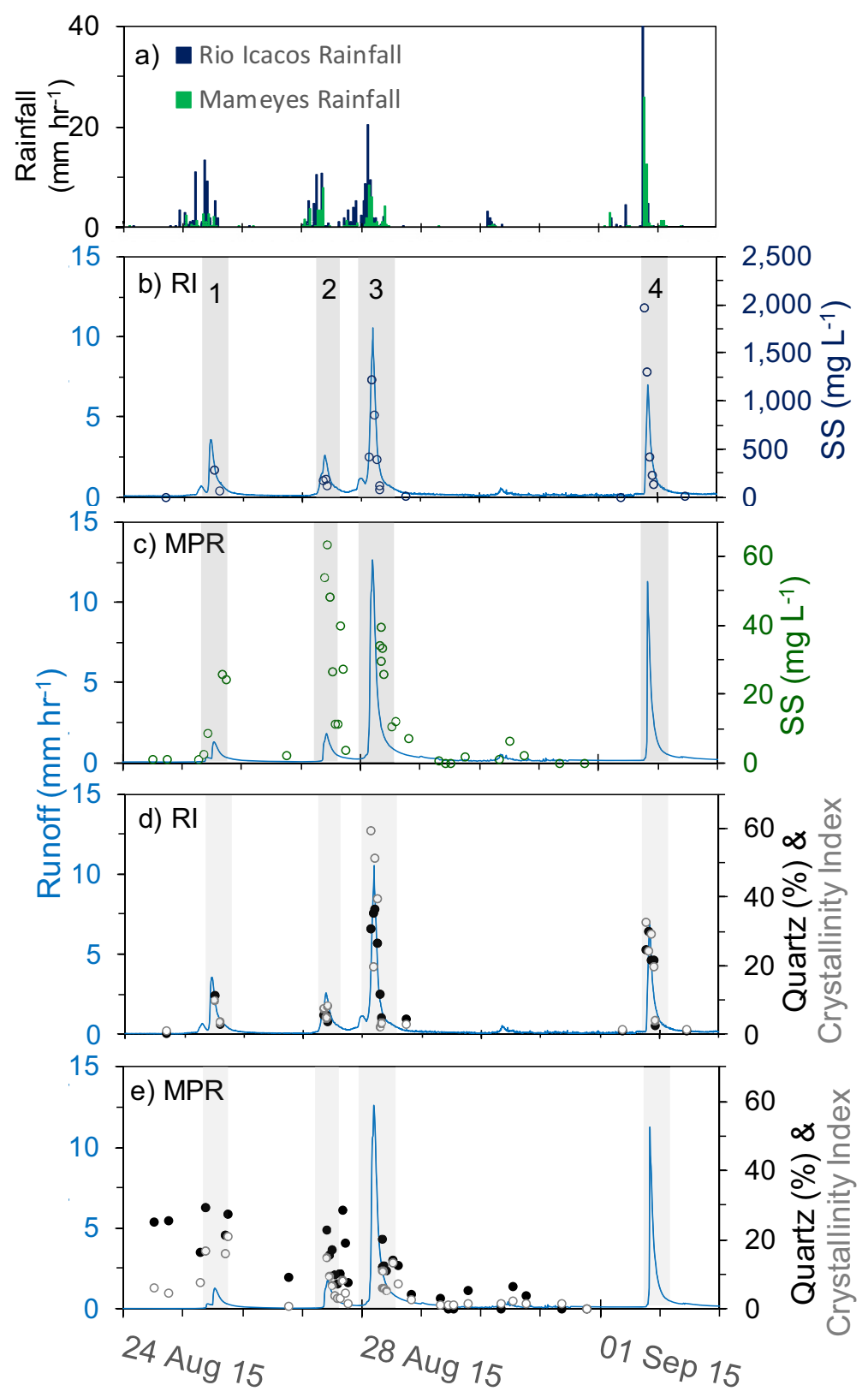

Figure 3. (a) Hourly rainfall at Rio Icacos (RI) gage and at Mameyes Puente Roto (MPR) measured at Sabana field station $\sim 3 \mathrm{~km}$ away from the stream gage. Hydrographs from the (b) RI and (c) MPR gages with suspended sediment samples as circles, and rainfall Events 1-4 labeled in the grey bands. Crystallinity index and percent quartz in the suspended sediment at (d) RI and (e) MPR. Sampling points outside of the grey shaded areas are labeled as base flow in Figure 8.

Samples were kept chilled and filtered as soon as possible in the laboratory. A known volume was filtered under vacuum using a preweighed $0.7 \mu \mathrm{m}$ glass-fiber membrane (Whatman GF/F, $42.5 \mathrm{~mm}$ ). Filter membranes were dried in individual aluminum weigh boats at $80^{\circ} \mathrm{C}$ directly after filtration and weighed. Suspended sediment concentration (SSC) was computed from the mass of particles and water volume filtered. Filters were stored in small zip-lock bags. Two aliquots of filtered water were collected in $60 \mathrm{~mL}$ acid-washed Nalgene bottles; one was held frozen and the other was held refrigerated until analysis, usually within a month.

\subsection{Solid Sample Collection and Processing}

Potential sources of particulate organic matter (POM)—soil, riverbed, "algae"/biofilm, and vegetation—were collected from the rivers and catchments in the LCZO. Subsamples were taken from selected soil samples 
from the Big Dig project in 2011 [Porder et al., 2015]. The soil samples included the organic horizon (humic layer), and mineral horizon (0-20 and 50-80 cm depths) from 8 plots each containing 9 pits within the MPR and RI catchments, with a few sites from outside the catchments in order to span the variety of soils and vegetation types found in the study catchments. Samples were pulverized in a ball mill and stored in glass vials until analysis. In mid-January 2016, a biofilm, which we refer to as algae and most likely to be periphyton biomass [Ortiz-Zayas et al., 2005], was collected from the surface of $\sim 20$ riverbed rocks in shallow slowmoving water at the banks of the MPR gage. Shortly after collection, the rock samples were brought to the $\mathrm{lab}$ and the material scraped off with a razor blade and dried on aluminium foil at $80^{\circ} \mathrm{C}$, then stored in a zip-lock bag until analysis. In June 2015, riverbed grab samples were collected by hand from the bank just outside the river at the two gages. The samples were dried at $80^{\circ} \mathrm{C}$, sieved using an automatic shaker at $>500,500-250,250-150,150-63,63-0 \mu \mathrm{m}$ size fractions and ground using a ball mill and stored in glass vials until analysis. In mid-January 2016, in-stream litter was collected by grab sampling at both the RI and MPR gages. The litter consisted of coarse POM gathered in pools in the riverbed, and comprised an assortment of leaves and twigs deposited in the river channel. The samples were dried at $40^{\circ} \mathrm{C}$ and pulverized in a Wiley mill.

\subsection{Analytical Methods}

\subsubsection{Water Isotope Analysis}

Determination of $\delta^{2} \mathrm{H}$ and $\delta^{18} \mathrm{O}$ was performed at the USGS Stable Isotope Laboratory by isotope-ratio mass spectrometry using a hydrogen-equilibration technique for $\delta^{2} \mathrm{H}$ and a $\mathrm{CO}_{2}$ equilibration technique for $\delta^{18} \mathrm{O}$ [Révész and Coplen, 2008a, 2008b]. The 1-sigma analytical uncertainty was $0.1 \%$ for oxygen and $1 \%$ for hydrogen isotopic values. Previous work has shown how rainfall isotopic composition correlates with weather patterns and elevation for the Luquillo Mountains [Scholl et al., 2009; Scholl and Murphy, 2014; Scholl et al., 2014], and the stream isotopic composition through the drought is interpreted in that context. Historical stable isotope data for rain, stream, and groundwater samples from this watershed are available in Scholl and Murphy [2014] and Scholl et al. [2015].

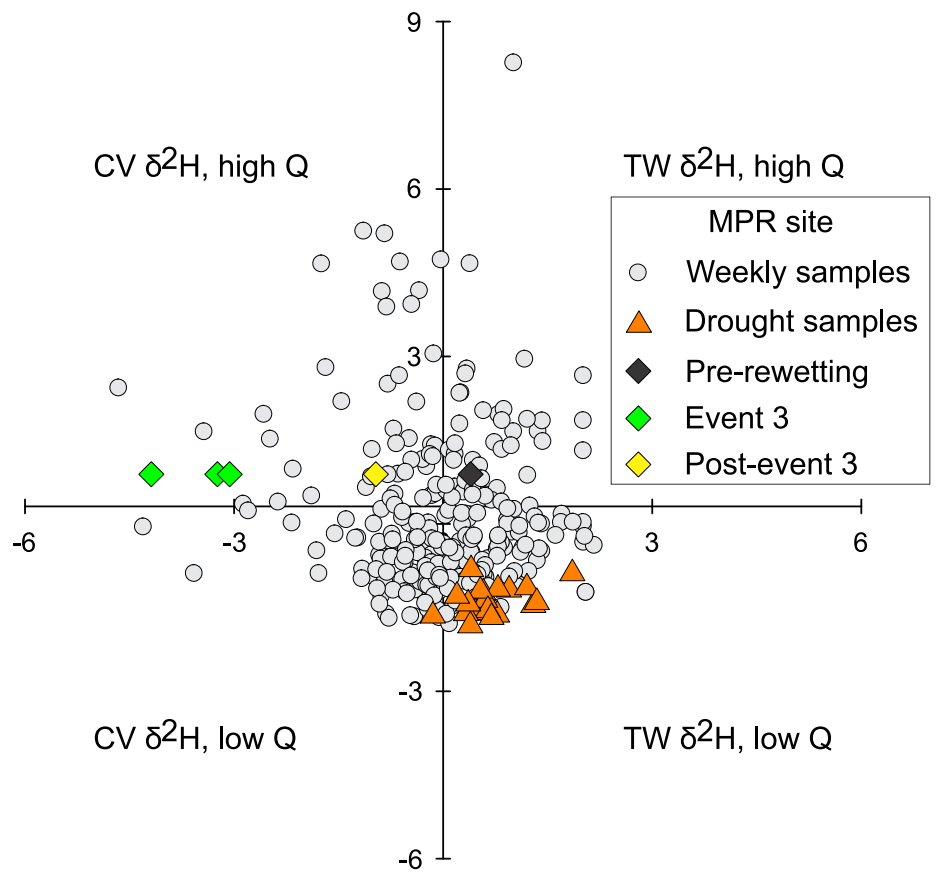

Figure 4. Z-scores for weekly $\delta^{2} \mathrm{H}$ of river samples ( $x$ axis) plotted against $\mathrm{z}$-scores of weekly discharge (Q) for the Rio Mameyes at Puente Roto (MPR) (y axis). The plot quadrants represent convective-source rainfall (CV) and trade-wind orographic source rainfall (TW) at relatively high or low discharge, based on previous isotope studies in the area [Scholl et al., 2009; Scholl and Murphy, 2014]. The 2015 drought samples, a pre-rewetting drought sample, Event 3 samples, and a post-Event 3 sample are shown in comparison to the longterm $\delta^{2} \mathrm{H}$ data set for the site.
To evaluate whether the isotopic composition and discharge for the summer drought samples were outliers compared to previous data, z-scores of discharge were calculated using the mean discharge from the week prior to the isotope sample, normalized to mean monthly discharge for the gaging station generated from 1991 to 2015. Z-scores of the weekly isotope values were normalized to mean and standard deviation of all stream isotope values $\left(\delta^{2} \mathrm{H}\right)$ from the 2007 to 2015 data set in Scholl et al. [2015] (Figure 4). The entire stream isotope data set was used, rather than monthly mean values, because of the high year-toyear variability in wet-season (summer) isotope values. Isotope values were from grab samples that represented instantaneous flow conditions, whereas stream discharge $(Q)$ was the weekly average. 


\subsubsection{Dissolved Organic Matter and Solutes}

Filtered water samples were analyzed for nutrients, organic matter, and major cations and anions at the University of New Hampshire. Ammonium was measured using the indophenol blue method using a SEAL AQ400 Discrete Analyser. Nitrate, sulfate, chloride, sodium, potassium, calcium, and magnesium were analyzed using ion chromatography (Dionex ICS-1100). Silica was measured on refrigerated samples using the molybdate blue method on a Westco SmartChem robotic analyser. Dissolved organic carbon (DOC) was measured as nonpurgeable organic carbon using high temperature platinum catalyzed combustion (Shimadzu TOCV). The Shimadzu TN module was used to measure total dissolved nitrogen. Dissolved organic nitrogen (DON) was estimated as the difference between total dissolved nitrogen and inorganic $\mathrm{N}$ (nitrate plus ammonium).

\subsubsection{Inorganic Particle Analysis}

Suspended sediment obtained on the filter membranes was analyzed by X-ray diffraction (XRD) and quantified using the Rietveld technique [Rietveld, 1967, 1969] using the Rietveld module included in the Highscore Plus software following a previously published method [Perdrial et al., 2014, 2015]. Diffractograms were acquired on a Panalytical X'Pert equipped with a Cu K $\mathrm{X}_{\alpha}$ X-ray tube and recorded between 5 and $75^{\circ} 2 \Theta$ at a resolution of $0.008^{\circ} 2 \Theta$ with a counting time of $179.705 \mathrm{~s} / \mathrm{step}$ at the University of Pennsylvania. Depending on available sample volume, diffractograms on sediments were acquired on powdered samples using standard $16 \mathrm{~mm}$ diameter circular sample holders (large volume). In the latter case, samples were analyzed on the filter and the filter background was subtracted before using the Rietveld module included in the X'Pert HighScore Plus software for quantitative analysis. All Rietveld simulations included a consistent set of reference minerals from the literature, the American Mineralogist Crystal Structure Database (AMCSD) and Crystallography Open Database (COD) [Downs and Hall-Wallace, 2003; Grazulis et al., 2009; Gražulis et al., 2012]. From the X-ray diffractograms, a crystalline index $(\mathrm{Cl})$ was determined, based on the ratio of the maximum peak intensity over the background amplitude (taken at low and high angles).

\subsubsection{Particulate Organic Matter}

The sediment mass $(\mathrm{mg})$ and known filtered volume (L) were used to calculate the suspended sediment concentration $\left(\mathrm{mg} \mathrm{L}^{-1}\right.$ ). Due to the lack of carbonate rocks present in the study areas, all carbon in the suspended sediment was assumed to be organic. As with the inorganic particle analysis, suspended sediment samples were treated differently depending on the quantity of material on the glass-fiber membranes. For low-SS samples, collected during low flow, one to two $16 \mathrm{~mm}$ diameter circles were punched from the sample filter. These were reweighed and SS mass determined by subtracting the corresponding mass of filter, determined by prorated area as $\mathbf{1 3 . 8 5 \%}$ of the initial whole filter mass. The majority of the glass fiber filter was removed with a razor blade and the sample, with minimal filter fibers on it, was placed in a tin capsule for analysis. The high-SS samples, collected during high flow, were rinsed off the filter with deionized water into a small beaker, dried at $40^{\circ} \mathrm{C}$, homogenized using a mortar and pestle, and transferred to glass vials. Aliquots of the suspended sediment sample $(5-10 \mathrm{mg})$ were placed in tin capsules for analysis.

Suspended sediment samples were run on a Costech ECS 4010 elemental analyzer (EA) at the University of Pennsylvania to determine their weight percent organic carbon $(\% \mathrm{C})$ and nitrogen $(\% \mathrm{~N})$, used to determine the $\mathrm{C} / \mathrm{N}$ ratio. Samples were also run for stable isotopes of $C\left(\delta^{13} \mathrm{C}\right)$ and $\mathrm{N}\left(\delta^{15} \mathrm{~N}\right)$. These isotopes were analyzed on a Delta Plus isotope-ratio mass spectrometer (IRMS) configured with an Elemental Analyzer (NA 2500) and Conflo III at the Academy of Science, Drexel University. The $\delta^{13} \mathrm{C}$ values were normalized relative to VPDB.

Given the $\% \mathrm{C}$ and $\% \mathrm{~N}$ variability in the potential POM sources, they were run first on the EA to determine the appropriate masses needed to obtain accurate $\delta^{13} \mathrm{C}$ and $\delta^{15} \mathrm{~N}$ results. Samples were packed into tin capsules at the appropriate masses (1-20 mg) and run on the EA-IRMS.

\section{Results}

\subsection{Hydrology}

\subsubsection{Hydrometeorology of the 2015 Drought}

The drought of 2015 in eastern Puerto Rico began during the winter dry season and intensified from May to August 2015. In the Luquillo Mountains, the drought was moderated by small rainfall events. At the RI rain gage, within the May to August drought period there were $\sim 25 \%$ fewer rainfall events (defined as $>0.16 \mathrm{~mm} \mathrm{~h}^{-1}$ ) and $\sim 60 \%$ fewer large rainfall events (>10 mm total rainfall) compared to the 20 year 
average [Scholl and Murphy, 2014]. The instantaneous streamflow just before the first event was at historically low levels, with an exceedance level $>99.4 \%$ at MPR and the lowest flow of record at RI. In the week before the rewetting events, $40 \%$ of the region was under extreme drought, with the remaining $60 \%$ under severe drought. After the rewetting events, however, the intensity of the extreme drought was reduced to $5 \%$, with 95\% under severe drought (Figure 1) [USDM, 2017]. Drought is defined by the U.S. Drought Monitor (USDM) as a moisture deficiency that has impacts on society, environment, or economy. Droughts are classified into five categories from abnormally dry to exceptional drought. The USDM incorporates five indices including soil moisture, streamflow, precipitation, and drought severity index. Extreme drought often causes major crop/pasture failure, and widespread water shortages or restrictions [USDM, 2016].

The focus of this study was four hydrologic events that occurred from 25 August to 1 September 2015 (Table 1), following 4 months of drought. Event 1 produced the largest discharge peak in 3 months, and Event 3 produced the largest discharge peak in 9 months. Event 4 had the greatest rainfall intensity of the four events [USGS, 2016b] (Table 1).

\subsubsection{Stream Hydrological and Isotopic Response}

To determine whether the isotopic composition of the stream during the drought was anomalous, the findings were compared to normalized values of isotopic composition and discharge. Normalized discharge ( $Q$ z-scores) were plotted against normalized isotopic composition $\left(\delta^{2} \mathrm{H}\right.$ z-scores) for stream water collected from MPR with each quadrant indicating a precipitation source and flow regime (Figure 4). The isotopic composition of synoptic-scale and local precipitation sources is well-understood for the Luquillo Mountains [Scholl et al., 2009; Scholl and Murphy, 2014], with trade-wind orographic precipitation isotope values being higher (isotopically enriched) compared to precipitation originating from deep convection or tropical storms (isotopically depleted). The stream stable isotope composition matches the seasonal cycle of precipitation isotope values closely in timing, but with damped isotopic values in stream water compared to precipitation [Scholl et al., 2015].

Figure 4 shows the seasonal behavior of the stream, with points near the middle of the plot representing mean conditions. The upper left quadrant has the most extreme flows and isotopic compositions (from tropical storms and hurricanes) and the lower right quadrant represents winter dry season conditions, with less-variable weekly streamflow and relatively constant isotopic composition of rainfall (daily trade-wind showers). The upper right quadrant of Figure 4 reflects cold fronts or strong trade winds, which can be characterized by high rainfall with higher isotopic values. Lastly, the lower left quadrant represents summer precipitation with low isotope values and lower-flow conditions.

The drought samples (late March 2015 to late August 2015) were at the outer edges of the normalized distribution for discharge (Figure 4), and appear to have a trade-wind orographic precipitation source; the samples do not plot in the left-side quadrants representing isotopic composition of deep convective rainfall. The $z$-scores for the drought samples were generally between -1 and -2 for discharge and between 0 and +2.5 for isotopic composition. Since the discharge $z$-scores were based on monthly normals, the negative z-scores indicated less than normal flow each month during the drought. Z-scores for isotopic composition are somewhat less informative, as they are based on the entire range of isotopic values for the area, but the weekly $\delta^{2} \mathrm{H}$ values of stream water during the spring-summer 2015 drought most often resembled the dry season (winter) composition of the stream. Stream $\delta^{2} \mathrm{H}$ composition ranged from $-5.6 \%$ to $-0.4 \%$, with a mean of $-3.5 \%$, while local groundwater $\delta^{2} \mathrm{H}$ is $-6.5 \%$, median stream $\delta^{2} \mathrm{H}$ is $-5.0 \%$, and the MPR longterm low-flow average $\delta^{2} \mathrm{H}$ value is $-4.6 \%$.

The strength and direction of the trade winds apparently were not affected by the strong El Niño in place at this time. The tropical-wave weather systems that make up normal summer rainfall occurred over the summer, but the isotopic signatures of the stream and the decrease in number of larger, intense rain events indicate that the usual deep convective processes were not as prevalent as in other summer wet seasons. Therefore, we surmise that the winter pattern of predominantly trade-wind showers remained an important precipitation source through the summer.

At Rl, we performed hydrograph separation by isotopes for Event 3 and by specific conductance for Event 4. The $\delta^{2} \mathrm{H}$ of rainfall for Event 3 (Tropical Storm Erika) was $-25.3 \%$. This measurement was at MPR and was adjusted for the elevation of RI to $-32.5 \%$, based on historical relations. This value was not as depleted as some tropical storms, where $\delta^{2} \mathrm{H}$ values as low as $-127 \%$ have been measured [Scholl et al., 2015], but 


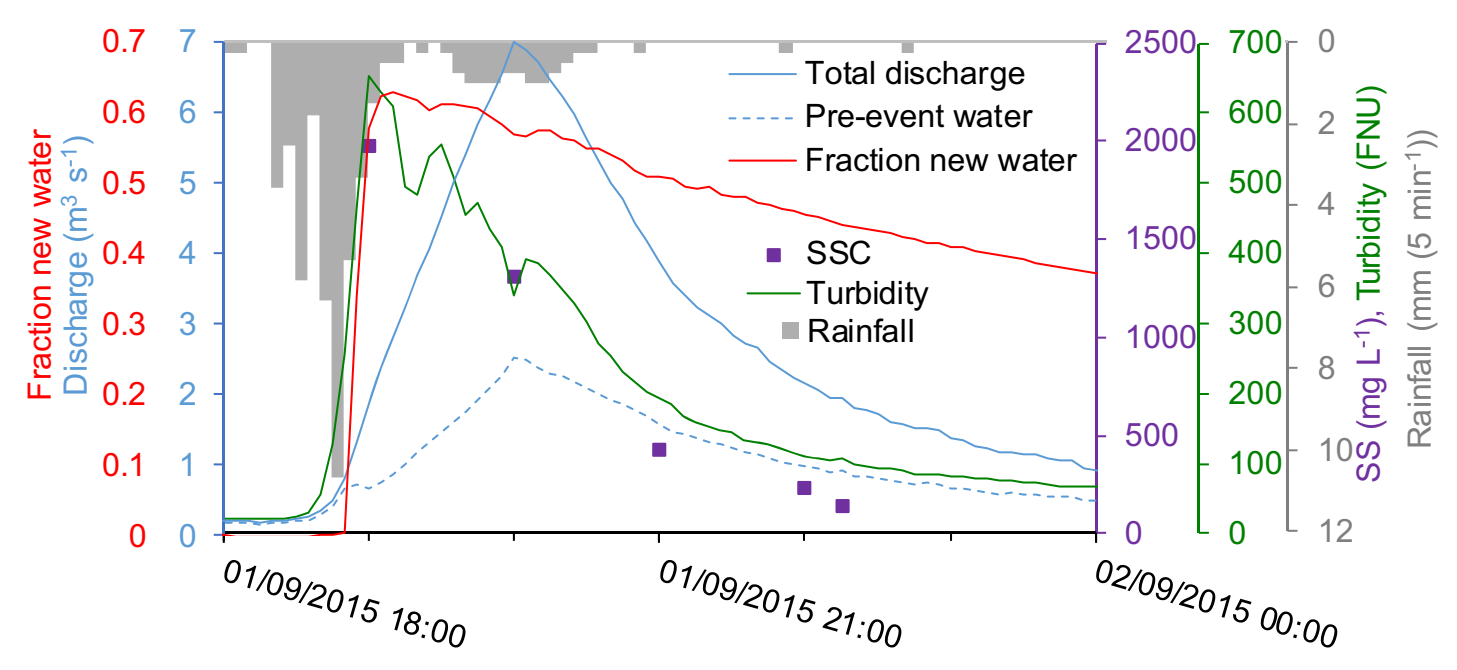

Figure 5. Hydrograph separation for Event 4 at the Rio Icacos gage based on high resolution in-stream sensors of specific conductance. The fraction new water (red) was determined from a simple two-component mixing model with base flow and event rainfall as end members. Also shown are turbidity (dark green) and 5 min rainfall amount (hanging grey bars). Suspended sediment (SS) (mg L ${ }^{-1}$ ) from grab samples (purple squares) track the rise and fall in turbidity.

allowed for a good separation from the pre-event RI base flow $\delta^{2} \mathrm{H}$ of $-9.2 \%$. The new water fraction ranged from 0.30 to 0.51 , with the highest fraction on the rising limb (supporting information Table 1). We had only falling limb samples for Event 3 at MPR so did not perform a hydrograph separation, but these samples plotted clearly in the tropical storm quadrant (isotope z-scores of -3.1 to -4.2 ; Figure 4).

Event 4 at the RI gage was the most intense storm during the study (Table 1). Fortunately, hydrograph separation of streamflow was possible using specific conductance. The specific conductance of base flow (57.6 $\left.\mu \mathrm{S} \mathrm{cm}{ }^{-1}\right)$ and rainfall $\left(5 \mu \mathrm{S} \mathrm{cm}^{-1}\right)$ were used in a mixing model to determine the contribution of new water

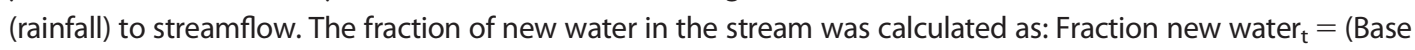
flow $\mathrm{SC}-$ Stream $\left.\mathrm{SC}_{\mathrm{t}}\right) /\left(\right.$ Base flow $\mathrm{SC}$ - Rainfall $\mathrm{SC}$ ), where Stream $\mathrm{SC}_{\mathrm{t}}$ is the stream water conductance at time t. During this intense event, the new water fraction increased rapidly after the onset of rainfall to a maximum of 0.62 , then decreased gradually to 0.56 at the discharge peak, which lagged $\sim 1 \mathrm{~h}$ behind the onset of intense rainfall (Figure 5), as is typical [Kurtz et al., 2011]. The new water fraction further decreased gradually to 0.38 four hours after the peak when discharge had recessed to $10 \%$ of its peak value.

\subsection{Stream Solute Dynamics}

In both streams, major solute concentrations during the rewetting events generally fell on the long-term C-Q relations (Figures $6 \mathrm{a}-6 \mathrm{~d}$ and supporting information Figure 1 and supporting information Table 2) [Shanley et al., 2011; Stallard and Murphy, 2012]. Ca, Mg, Na, and Si diluted with increasing flow, as is typical. At Rl, concentrations of these solutes were somewhat elevated within the historic C-Q data "cloud" except for $\mathrm{Si}$, which was about average (Figures $6 \mathrm{c}$ ). At MPR, Ca, Mg, and Na were near average and Si was somewhat below average. Also as is typical, $\mathrm{K}, \mathrm{Cl}$, and $\mathrm{NO}_{3}$ showed little response to flow (supporting information Figure 1). $\mathrm{Cl}$, which usually shows a slight dilution, actually increased with flow at MPR, where it was also near the upper bound of the historic $\mathrm{C}-\mathrm{Q}$ envelope. Like the other base cations, $\mathrm{K}$ concentrations were somewhat elevated at $\mathrm{RI}$. $\mathrm{SO}_{4}$ followed the historic patterns at each site, but was near the upper bound of the respective $\mathrm{C}-\mathrm{Q}$ relations. At RI, DOC concentrations increased linearly with an increase in discharge until a threshold near $1 \mathrm{~mm} \mathrm{~h}^{-1}$, above which DOC concentrations did not increase further, which is consistent with the long-term pattern (Figure 6a). At MPR, DOC concentration increased monotonically with discharge, consistent with the long-term pattern, albeit at a lesser slope (Figure 6b).

\subsection{Stream Particle Dynamics}

\subsubsection{Total Suspended Sediment}

For all streams and events, suspended sediment (SS) concentrations increased with an increase in runoff and overlapped well with the long-term SS concentration-discharge (C-Q) relationship (weekly samples including events since 1991, $\mathrm{n}=\sim 4400$ (Figures 6e and 6f; supporting information Table 3a)) [McDowell 

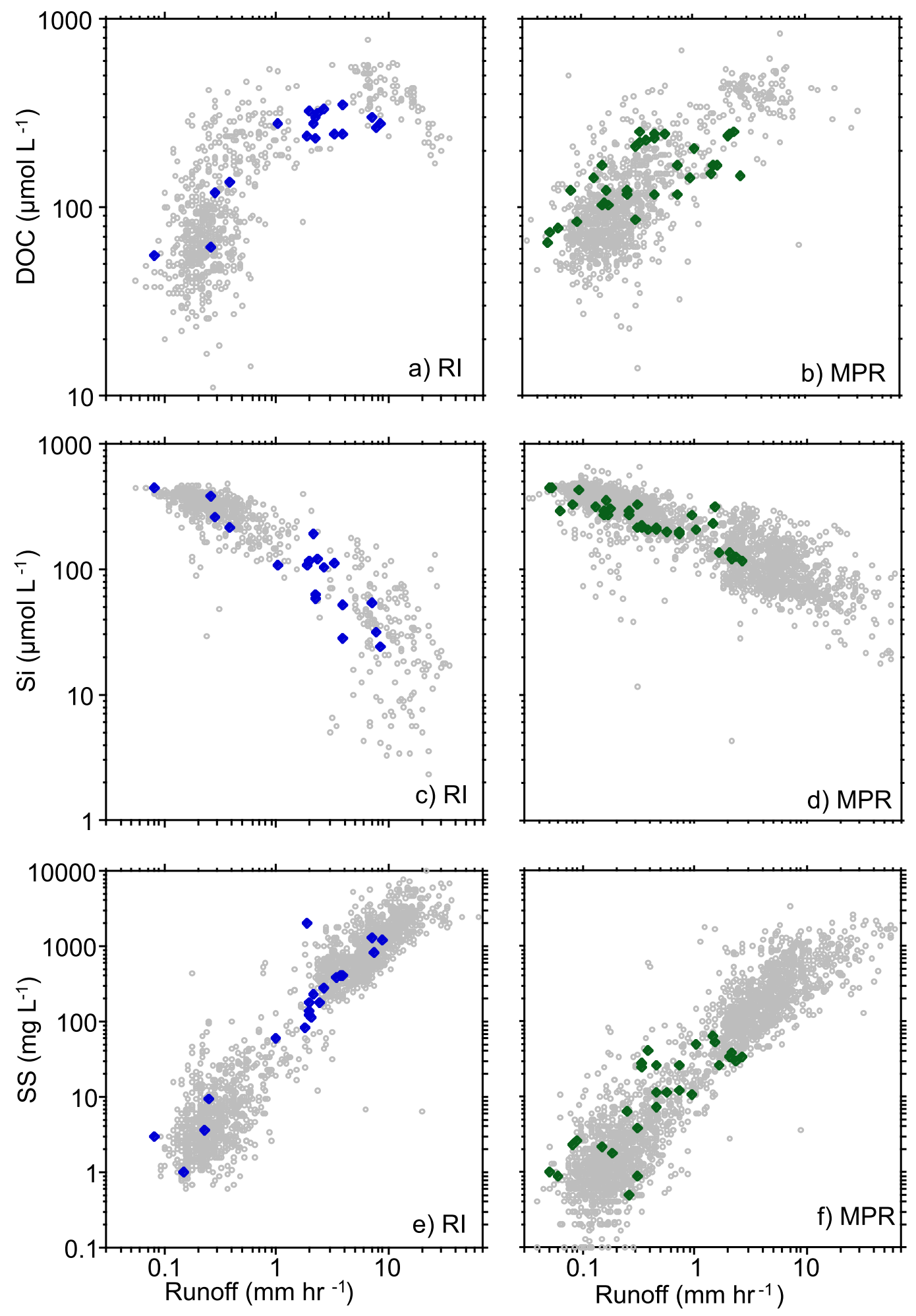

Figure 6. Concentration-discharge (C-Q) plots from the rewetting events in for the Rio Icacos (RI in blue) and Mameyes (MPR in green) overlaid on the long-term data sets (grey circles): (a) dissolved organic carbon (DOC) at Rl; (b) DOC at MPR; (c) Si at Rl; (d) Si at MPR; (e) suspended sediment (SS) at Rl; (f) SS at MPR. The long-term data set values are from the Luquillo Critical Zone Observatory (LCZO), Luquillo Long Term Ecological Research (LUQ LTER) and U.S. Geological Survey (USGS) [McDowell and Asbury, 1994; Shanley et al., 2011; Stallard, 2012; Stallard and Murphy, 2012]. Similar paired plots are presented for $\mathrm{Ca}, \mathrm{Mg}, \mathrm{Na}, \mathrm{K}, \mathrm{Cl}$, and $\mathrm{NO}_{3}$, and $\mathrm{SO}_{4}$ in supporting information Figure 1. 


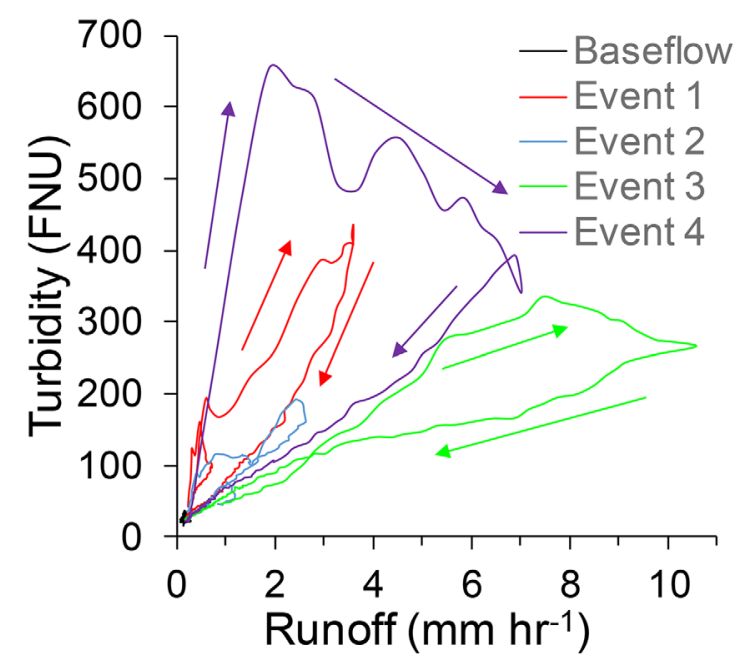

Figure 7. Clockwise hysteresis loops for turbidity (FNU), a proxy for particulate load, for Events 1, 3, and 4 at Rio Icacos (RI) with discharge. and Asbury, 1994; Stallard, 2012]. High-resolution in-stream turbidity, a proxy for SS, measured at $\mathrm{Rl}$ over the study, produced distinctive clockwise hysteresis patterns with discharge for each rainfall event (Figure 7). SS correlated strongly with turbidity, a common proxy for SS concentration [Gippel, 1995; Lewis, 1996]. SS-Q hysteresis at RI was clockwise, consistent with an earlier study that found clockwise hysteresis in $80 \%$ of the storm events sampled at RI [Gellis, 2013]. Event 4 , with the most intense rainfall, produced the largest hysteresis loop (Figure 7). SS and turbidity peaked on the rising limb shortly after the onset of intense rainfall, then declined steadily thereafter (Figure 5).

\subsubsection{Suspended Sediment Mineralogy}

The mineralogy of inorganic suspended sediment determined by X-ray diffraction at both RI and MPR consisted of quartz, plagioclase, amphibole, gibbsite, kaolinite, and 2:1 chlorite-like clay minerals (supporting information Table 4). At Rl, excluding base flow samples, the quartz fraction increased linearly with discharge at a similar slope for each event (Figure 8a). At MPR, however, successive rainfall events produced less and less quartz in the stream despite increasing discharge (Figure $8 \mathrm{~b}$ ). The X-ray
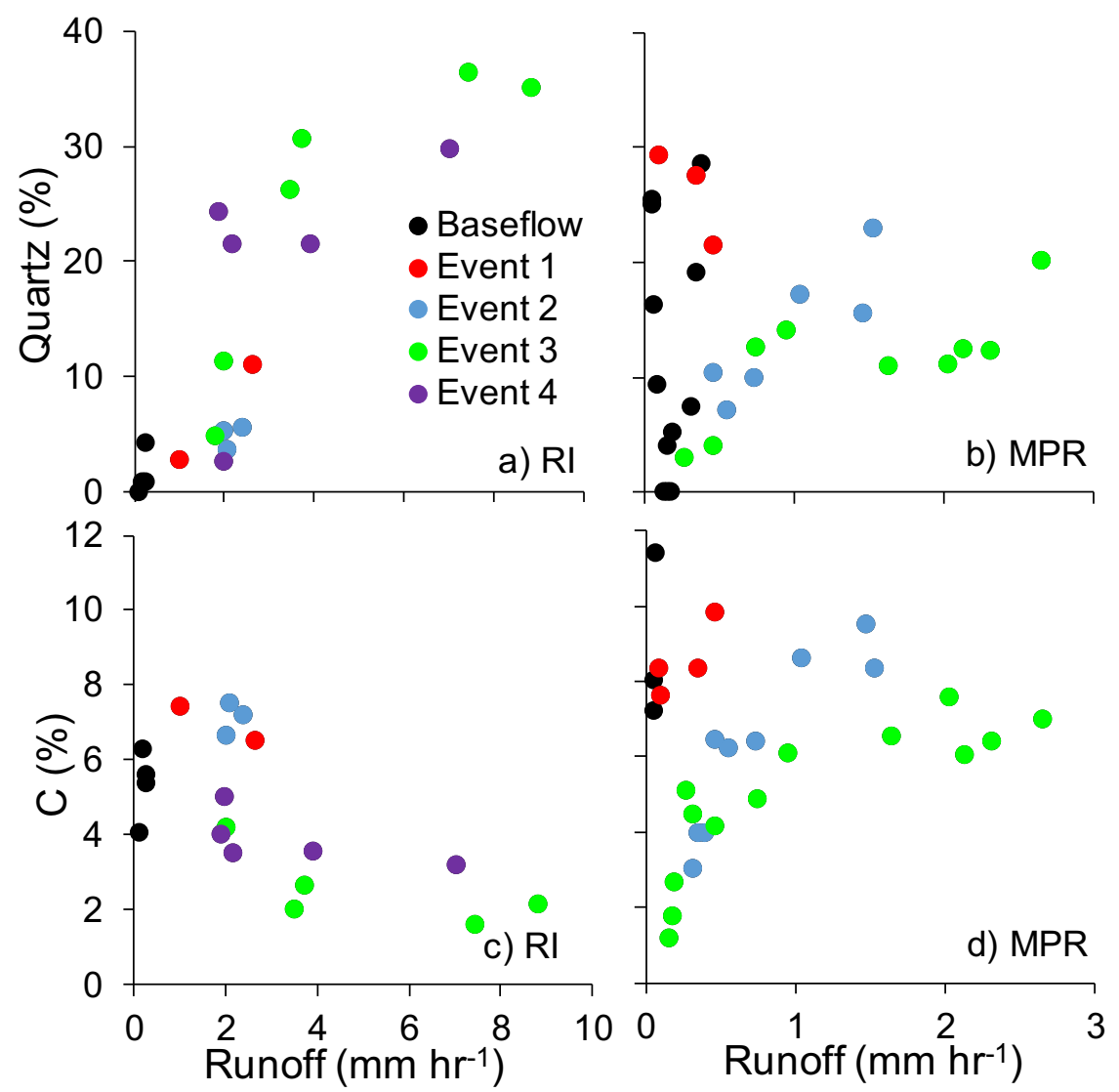

Figure 8. Percentage of quartz in the suspended sediment determined by quantitative X-ray diffraction (XRD) as a function of discharge in the (a) Rio Icacos (RI) and (b) Rio Mameyes (MPR) rivers during the sampling period. Percentage of particulate organic carbon (\%C) in the suspended sediment as a function of runoff in the (c) RI and (d) MPR catchments. 
derived crystallinity index $(\mathrm{Cl}$, a measure of crystalline minerals), increased with increasing discharge in both rivers (Figures $3 d$ and $3 e$ ).

\subsubsection{Particulate Organic Matter}

River POC and PN were variable over the series of rewetting events, ranging from 2 to $10 \% \mathrm{C}$ and $\sim 0.1$ to $1.2 \% \mathrm{~N}$ (Figures $8 \mathrm{c}$ and $8 \mathrm{~d}$; supporting information Figure 2 and supporting information Table 3b). Event 1 at MPR and Events 1 and 2 at RI maintained a higher POM, similar to drought base flow (Figures $8 \mathrm{c}$ and $8 \mathrm{~d}$ ). During the later events, the two rivers behaved differently. At MPR, POM increased with discharge, whereas at $\mathrm{RI}, \mathrm{POM}$ decreased with discharge (Figures $8 \mathrm{c}$ and $8 \mathrm{~d}$; supporting information Figure 2). C/N varied over the sampling period, where the lowest $\mathrm{C} / \mathrm{N}$ occurred during base flow in both rivers and increased during the rewetting events (Figures $9 \mathrm{a}$ and $9 \mathrm{~b}$ ). $\mathrm{C} / \mathrm{N}$ was distinctly greater at $\mathrm{Rl}$ and was largely influenced by smaller \%C for RI versus MPR (Figures 9a, 9b, 8c, and 8d; supporting information Figure 2). Values of $\delta^{13} \mathrm{C}$ varied from $-27.1 \%$ to $-29.4 \%$ at MPR and $-28.0 \%$ to $-28.9 \%$ at RI (Figures $9 \mathrm{c}$ and $9 \mathrm{~d}$ ). Values of $\delta^{15} \mathrm{~N}$ varied to a greater extent especially at MPR, ranging from $-2.00 \%$ o to $3.46 \%$ at MPR and $0.66 \%$ o to $1.88 \%$ o at RI (Figure 9). C/N ratios and isotopic signatures $\left(\delta^{13} \mathrm{C}\right.$ and $\left.\delta^{15} \mathrm{~N}\right)$ of the potential river POM sources (mineral soil $(0-80 \mathrm{~cm})$, and organic soil and vegetation) varied only slightly between the two catchments (Figure 9). The riverbed material represented a well-mixed contribution of catchment sources (terrestrial and riverine) and was similar between the two rivers, but differed for $\delta^{13} \mathrm{C}$, where RI samples were found less variable than those from MPR (Figure 9). The "algae" end member reflected the in-stream source of periphyton biomass, and was only evident at MPR (Figure 9).
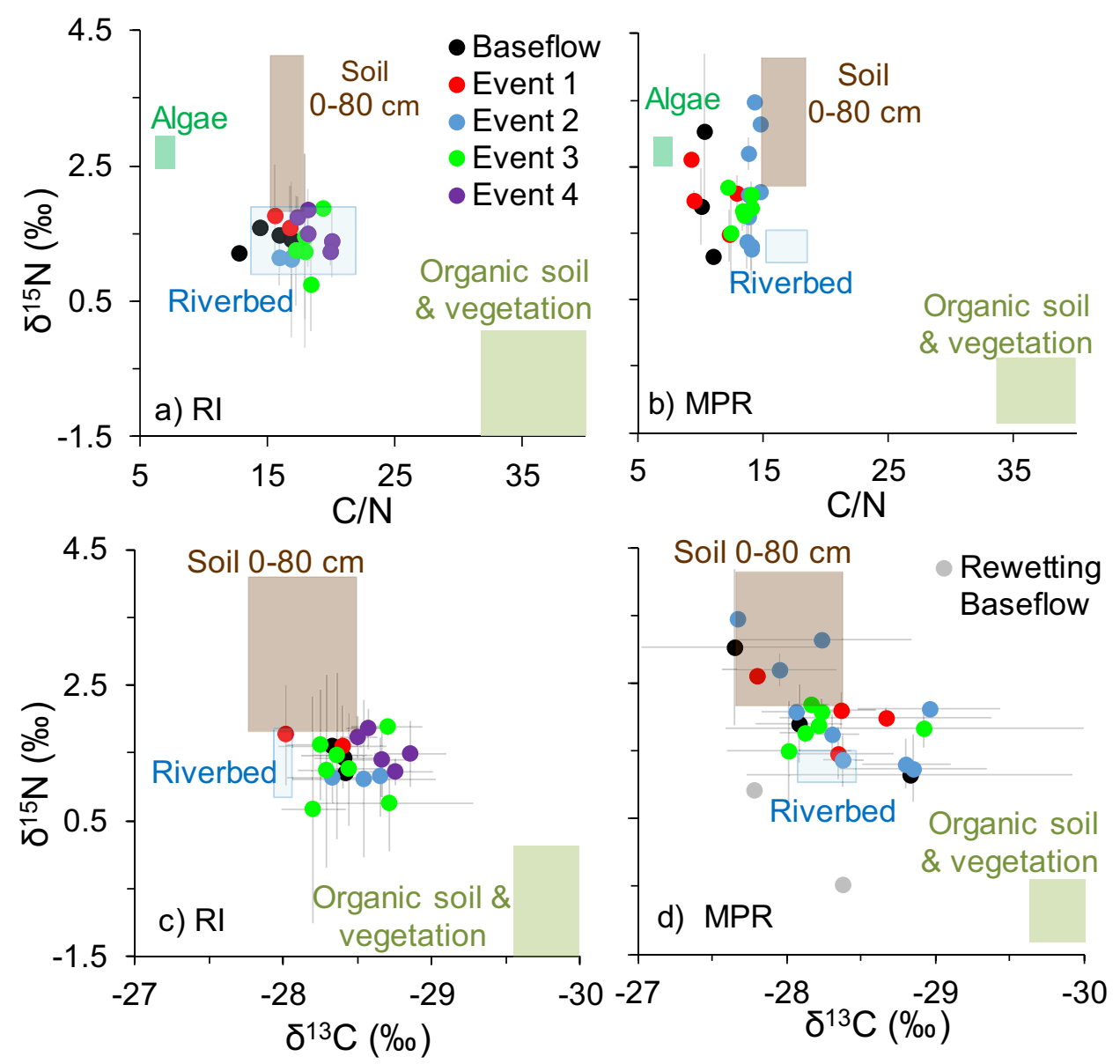

Figure 9. $\delta^{15} \mathrm{~N}$ versus $\mathrm{C} / \mathrm{N}$ of river particulate matter for (a) Rio Icacos (RI) and (b) Mameyes (MPR), and $\delta^{15} \mathrm{~N}$ versus $\delta^{13} \mathrm{C}$ for (c) RI and (d) MPR. The whiskers on the river samples represent one standard deviation of the mean. The potential sources: algae, mineral soil (0$80 \mathrm{~cm}$ ), riverbed sediment, and organic soil and vegetation are outlined in supporting information Table 5, where the boxes represent $2 \times$ standard error around the mean. Algae is not shown in Figures $9 \mathrm{c}$ and $9 \mathrm{~d}$ as it had an extremely enriched $\delta^{13} \mathrm{C}$ at $-16 \%$ (supporting information Table 5). 
At MPR, POM during drought base flow was dominated by "algae," with mineral soil $(0-80 \mathrm{~cm})$ and riverbed possibly contributing as well (Figure 9d). Upon rewetting, however, the source shifted toward mineral soil and riverbed POM (Figure 9b), with a potential contribution from organic soil and vegetation (Figure 9d). At $\mathrm{Rl}$, drought base flow POM appeared to be mostly riverbed material (Figure 9a). Rewetting in RI yielded POM representing a mix of riverbed sediment and mineral soil $(0-80 \mathrm{~cm})$, as well as organic soil and vegetation from the catchment (Figure 9c). In general, MPR had a lower $\mathrm{C} / \mathrm{N}$, more enriched $\delta^{15} \mathrm{~N}$, and more depleted $\delta^{13} \mathrm{C}$ than $\mathrm{Rl}$, which is consistent with the influence of the in-stream biofilm "algae" in the MPR catchment (or another $\mathrm{N}$-rich source that we did not measure) (Figure 9).

\section{Discussion}

\subsection{Concentration-Discharge Relationships}

$\mathrm{C}-\mathrm{Q}$ relationships, and how they may shift in response to events, can help elucidate the processes driving riverine solute and suspended sediment dynamics [Brooks et al., 2015; Herndon et al., 2015]. Drought can affect $\mathrm{C}-\mathrm{Q}$ relationships by limiting water throughput and altering flow paths in extremely dry soils. The lack of regular flushing by rainfall may lead to a build-up of solutes in the catchment. Here, we evaluated C-Q relationships in these rewetting events in the context of long-term relations at the sites to understand how the system responds to extreme drought. While most solute concentrations during the rewetting events generally plotted on the long-term C-Q relationships, base cations at RI generally plotted above the central tendency of the long-term data, suggesting some flushing of solutes stored during the drought. At both sites, sulphate was the solute closest to the upper bound of the long-term C-Q relationship. Elevated sulfate is suggestive of oxidation of sulfide minerals exposed to oxygen during low water tables, with the resulting sulfate flushed during the rewetting events [Eimers et al., 2004; Mayer et al., 2010].

The SS-Q relationship during the study overlapped neatly within the long-term relationship for both streams (Figures $6 e$ and 6 f). The long-term data set represents hundreds of samples, ranging from low flow to extremely high runoff in hurricanes [Stallard and Murphy, 2012]. Clockwise SS-Q hysteresis regularly occurs at Rl, as previously noted by Gellis [2013], and demonstrated during the four rewetting events by the high-resolution in-stream turbidity measurements at RI (Figure 7). This hysteresis generates a great deal of the inherent scatter in the SS-Q relation, as maximum turbidities can occur quite early on the rising limb and individual SS-Q loops can occupy mutually exclusive SS-Q space, as for Events 3 and 4 (Figure 7). Nonetheless, conformance to the long-term SS-Q relationship indicates that there was no significant "store and release" of SS as a result of the drought. We note that the upper boundary of the SS-Q relation is likely controlled by the stream response to frequent landslides, and to our knowledge there were no recent or active landslides at the time of the study.

\subsection{Sources of Organic and Inorganic Particulates}

Physical differences between the two catchments gave rise to contrasting behavior of SS in the two rivers. RI has greater annual runoff and SS yield [Stallard and Murphy, 2012], due to high rainfall in this small, highelevation catchment [Murphy et al., 2012]. Higher SS concentrations are driven by the large volume of sandsized quartz grains stored in the channel (Figure 2). The upper reaches in the MPR catchment have the same quartz diorite bedrock as RI and the channel is similarly dominated by quartz sand (Figure 2). The volcaniclastic bedrock in the lower reaches of MPR is more stable [Phillips and Jerolmack, 2016], with chemical weathering controlling its breakdown. Thus the channel in the volcaniclastic reach is relatively devoid of fine sediment, rather is dominated by cobbles and boulders. Given the lower importance of an in-channel SS source at MPR, the source of SS throughout the rewetting events was less likely to have been affected by the drought (Figures $6 \mathrm{e}$ and $6 \mathrm{f}$ ).

\subsubsection{Inorganic Particulates}

The suspended mineral composition at RI during the rewetting events was strongly related to discharge, where an increase of discharge resulted in an increase of \% quartz (Figure 8a). Because quartz is ubiquitous and plentiful in riverbed sediment and physically weathering saprolite, suspended mineral contribution from quartz is likely transport limited. The MPR catchment is more variable because quartz grains sourced from sandy bed sediment in the upper reaches dominates river suspended mineral load only at discharges $>2 \mathrm{~mm} \mathrm{~h}^{-1}$ (Figure 8b). The lowest flows had a range of quartz content, likely because at low discharge, suspended load is dominated by POM, rather than clay minerals such as kaolinite (R. Stallard, unpublished 
data). Thus, even a small amount of available quartz minerals in the riverbed can dominate the suspended mineralogy at low SS concentrations. This phenomenon is not observed at low discharges in the Rl, which carries a persistent supply of suspended clay-sized particles (R. Stallard, unpublished data), sourced from the riverbed and banks.

\subsubsection{Organic Particulates}

In the RI catchment, there was a high degree of mixing of POM sources in the river load, as evidenced by the relatively consistent isotopic ratios of $\mathrm{C}$ and $\mathrm{N}$ during storms and base flow. One reason for this was that there was not a distinct in-stream source, like the "algae" in MPR (Figure 9). Because of the POM mixing during the drought and rewetting events, it is difficult to determine where the OM material originated. The channel banks consist of clay soil and saprolite, which may provide a constant source of older OM that would moderate the stable isotope and C/N signature of riverine POM. The MPR catchment behaved quite differently. First, there was a distinct in-stream end-member at MPR with a depleted $\delta^{13} \mathrm{C}$ signature that dominated base flow and initial rewetting, imparting isotopic variability to the river POM. Second, there was likely a considerable amount of POM source switching over the hydrograph with individual river samples resembling distinct end-members (in-stream "algae," mineral soil, and organic soil and vegetation) (Figure $9 \mathrm{~b}$ and $9 \mathrm{~d}$ ). Specifically, river POM during the initial events likely had an important contribution from the in-stream "algae," but as the events progressed there was catchment input of POM sourced from mineral soil, and organic soil and vegetation (Figure 9b). Finally, the larger size of the MPR catchment may have affected the dynamics of POM delivery from its various sources to the gage. Although the drought impacted the two catchments in similar ways, their contrasting geologies caused a differential POM response to rewetting.

\subsection{Resistance and Resilience to Drought}

River biogeochemistry during drought rewetting events in the Luquillo Mountains appears to be resistant to drought, with no observable responses that could be clearly attributed to the extreme drought. Generally, the river solute biogeochemistry did not deviate from long-term C-Q relationships (Figure 6a-6d and supporting information Figure 1), although some higher concentrations were attributed to flushing of stored solutes at Rl, and transport of sulfate generated from sulfide oxidation in both catchments. One possible explanation is that the "capacity" of the watersheds to supply solutes was changed little by drought, implying a stable, resistant system. In Luquillo most solutes have also been shown to be resistant to major disturbance events, such as extreme drought and hurricanes, with the exception of $\mathrm{NO}_{3}$ and $\mathrm{K}[\mathrm{McD}$ owell et al., 1996; Schaefer et al., 2000; McDowell et al., 2013]. The lack of response in DOC, $\mathrm{NO}_{3}$, and K concentrations is particularly surprising, given the extent to which the increased litter fall associated with this drought (increase of 2.5-fold in total litterfall; J. Zimmerman, personal communication, 2016, University of Puerto Rico, Rio Piedras Campus) might be expected to increase DOC and $\mathrm{K}$ concentrations due to leaf leaching [e.g., Heartsill-Scalley et al., 2007] and the potential for $\mathrm{NO}_{3}$ to be immobilized by microbial processes during leaf decomposition [Zou et al., 1995]. Our results suggest that the controls exerted by hydrologic flow paths [Shanley et al., 2011] and soil sorption [McDowell, 1998], which result in a strong increase in DOC concentration at high streamflow throughout the Luquillo Mountains [McDowell and Asbury, 1994; Shanley et al., 2011; Stallard and Murphy, 2012] were not overridden by the extreme conditions and increased leaf litter inputs associated with this drought. This suggests that even during droughts, watershed-scale influences on flow paths and soil dynamics drive stream chemistry in response to droughts, as has already been documented for hurricanes [McDowell and Liptzin, 2014].

The response of particulate concentrations to rewetting events also showed a strong resistance of the rivers to drought. As we initially expected, we observed that POM and inorganic particulates in transport were derived primarily from in-channel sources during the initial rewetting events, but after this initial event we could find no evidence of enhanced in-stream sources. Despite the large influx of "new water" to the streams during these events, the delivery of materials from the landscape was similar to that observed during nondrought periods, suggesting that accumulation of particulate matter along catchment flow paths is not enhanced during droughts.

The Luquillo Mountain forests respond ecologically to drought through reduced primary production and increased litterfall [Beard et al., 2005]. In the rivers, the response is a reduction of food sources and habitats for shrimp as pools dry out, resulting in population isolation and decline [Covich et al., 2003]. The mountain ecosystems are resilient, however, with primary production and freshwater shrimp populations recovering 
rapidly post-drought [Covich et al., 2003; Beard et al., 2005]. In general, the Luquillo Mountain ecosystems are resilient to various types of disturbances, such as hurricanes, floods, droughts, and landslides [Larsen and Simon, 1993; Larsen, 2000; Beard et al., 2005; Covich et al., 2006; Larsen, 2012; Lugo and Heartsill Scalley, 2014].

\subsection{Implications for the Future}

The Caribbean is projected to warm in the coming century, with lower rainfall and more intense cyclonic activity [Chou et al., 2012; IPCC, 2013]. Potential drivers of increased drought frequency in the future include the projected strengthening of the Caribbean Low-Level Jet (CLLJ) in July of the wet season, which would diminish convective storms and reduce the length of the rainy season [Taylor et al., 2011], with high vertical wind shear which reduces cyclonic activity in the Caribbean [Goldenberg et al., 2001], and suppression of convection during strong El Niño events [Neelin et al., 2003].

The frequency of precipitation during drought will determine drought resiliency in the future. During this drought, the smaller trade-wind showers (orographic precipitation) persisted, while the larger convective storms diminished (Figure 4). This pattern represents another example of drought resistance, as it is the frequent orographic showers that recharge and supply base flow, while much of the water from the larger convective storms runs off [Scholl and Murphy, 2014]. However, a warming climate may cause cloud base to rise, or otherwise affect orographic cloud dynamics on the island. This would result in a decrease in orographic precipitation [Scholl and Murphy, 2014], increasing the likelihood of severe drought, and compromising the resistance and resiliency of the ecosystem to drought. General Circulation Models (GCMs) miss orographic precipitation, because it is small-scale and specific to mountain areas, but it can be simulated by Regional Climate Models (RCMs) [Karmalkar et al., 2011; Scholl and Murphy, 2014]. Thus, for a more realistic result, it is important to include RCMs in climate projections for Puerto Rico.

\section{Conclusions}

A 4 month drought in eastern Puerto Rico, reaching extreme drought at its peak, was partially alleviated by a series of four storms in late August and early September 2015. We intensively monitored two montane streams on contrasting lithologies, part of the Luquillo Critical Zone Observatory, through these events. We anticipated that these rewetting events would mobilize disproportionately high quantities of solutes and sediments that had accumulated in the catchments, but concentrations instead followed the long-term concentration-discharge (C-Q) relations for all constituents and both streams. Ironically, it was the fourth storm that pushed the envelope of the $\mathrm{C}-\mathrm{Q}$ relation for suspended sediment (SS). The high rainfall intensity of Event 4 appeared to be more important than the ongoing drought in driving high stream SS concentrations.

We further investigated effects of the drought by analyzing for shifts in sources of water, solutes, and sediment from drought base flow through the progression of storms. Base flow was driven by recharge from frequent and numerous small orographic precipitation events. We postulated that high soil moisture deficits would limit new water contributions to streamflow during storms, but such was not the case at least for Event 4, perhaps due to its extreme intensity. At Rl, on quartz diorite bedrock, the suspended sediment had the elemental composition and isotopic signature of streambed and soil in the first storms, but shifted somewhat toward a more organic-soil signal in Event 4. The mineralogy of the suspended sediment became more crystalline (quartz-dominated) as flow increased. Consistent clockwise C-Q hysteresis loops in real-time turbidity suggested a proximal source of sediment to the stream and possible supply limitation.

Future climate projections suggest that the Caribbean region, including Puerto Rico, will see less convective summer precipitation due to changes in the Caribbean Low Level Jet (CLLJ) and subsidence (which makes it hard for convection to occur), and that regional rainfall variability due to El Niño-Southern Oscillation (ENSO) cycles is likely to intensify [IPCC, 2013]. A separate issue of equal concern is that cloud base levels may rise to an altitude that decreases or eliminates interactions between the topography and the clouds. This would reduce the orographic precipitation that dominated recharge during the drought, and would thereby have an intensifying effect on droughts. In the short term, the 2015 drought appeared to have a limited effect on biogeochemical dynamics of stream water. Individual storm characteristics such as rainfall 
intensity played a greater role than drought. This apparent drought resistance may be tested by a more persistent climatic shift to drier conditions.

\begin{abstract}
Acknowledgments
We gratefully acknowledge support for K.C., A.P., and W.M. from the NSF Critical Zone Observatory program (EAR-1331841) and for J.S. and M.S. from the U.S. Geological Survey Water, Energy, and Biogeochemical Budgets (WEBB) program under Climate Research and Development. Angel Torres, Scott Albright, and Josh Brown helped greatly with field sampling and sample processing. Miriam Salgado and Grizelle Gonzalez of the USDA Forest Service International Institute of Tropical Forests (IITF) provided valuable local support on sampling logistics. Additional support was provided by the University of Puerto Rico and the LUQ LTER program (NSF DEB-1546686). John Franco Saraceno helped to verify and correct the field sensor measurements. Paula Zelanko, David Velinsky, David Vann, and Jody Potter provided laboratory analyses. Miguel Leon provided data support for the LCZO. All data are available on the Luquillo Critical Zone Observatory website: http://criticalzone.org/ luquillo/data/dataset/5668/. Any use of trade, firm, or product names is for descriptive purposes only and does not imply endorsement by the U.S. Government. We thank the editor D. Scott Mackay, the associate editor Erich Hester, reviewers Diana Karwan and Tom Huntington (USGS), and two anonymous reviewers for their thoughtful comments and suggestions that greatly improved the manuscript.
\end{abstract}

\section{References}

Bawiec, W. J. (Ed.) (1999), Geology, geochemistry, geophysics, mineral occurrences and mineral resource assessment for the Commonwealth of Puerto Rico, U.S. Geol. Surv. Open File Rep. 98-38, 1-337.

Beard, K. H., K. A. Vogt, D. J. Vogt, F. N. Scatena, A. P. Covich, R. Sigurdardottir, T. G. Siccama, and T. A. Crowl (2005), Structural and functional responses of a stubtropical forest to 10 years of hurricanes and droughts, Ecol. Monogr., 75(3), 345-361, doi:10.1890/04-1114.

Brocard, G. Y., J. K. Willenbring, F. N. Scatena, and A. H. Johnson (2015), Effects of a tectonically-triggered wave of incision on riverine exports and soil mineralogy in the Luquillo Mountains of Puerto Rico, Appl. Geochem., 63, 586-598, doi:10.1016/j.apgeochem.2015. 04.001.

Brooks, P. D., J. Chorover, Y. Fan, S. E. Godsey, R. M. Maxwell, J. P. McNamara, and C. Tague (2015), Hydrological partitioning in the critical zone: Recent advances and opportunities for developing transferable understanding of water cycle dynamics, Water Resour. Res., 51, 6973-6987, doi:10.1002/2015WR017039.

Burt, T. P., F. Worrall, N. J. Howden, and M. G. Anderson (2015), Shifts in discharge-concentration relationships as a small catchment recover from severe drought, Hydrol. Processes, 29(4), 498-507, doi:10.1002/hyp.10169.

Chou, C., C.-A. Chen, P.-H. Tan, and K. T. Chen (2012), Mechanisms for global warming impacts on precipitation frequency and intensity, J. Clim., 25(9), 3291-3306.

Clark, K. E., R. G. Hilton, A. J. West, Y. Malhi, D. R. Gröcke, C. L. Bryant, P. L. Ascough, A. Robles Caceres, and M. New (2013), New views on "old" carbon in the Amazon River: Insight from the source of organic carbon eroded from the Peruvian Andes, Geochem. Geophys. Geosyst., 14, 1644-1659, doi:10.1002/ggge.20122.

Clark, K. E., et al. (2016), Storm-triggered landslides in the Peruvian Andes and implications for topography, carbon cycles, and biodiversity, Earth Surf. Dyn., 4, 47-70, doi:10.5194/esurf-4-47-2016.

Connell, J. H. (1978), Diversity in tropical rain forests and coral reefs, Science, 199(4335), 1302-1310, doi:10.1126/science.199.4335.1302.

Covich, A. P., T. A. Crowl, and F. N. Scatena (2003), Effects of extreme low flows on freshwater shrimps in a perennial tropical stream, Freshwater Biol., 48(7), 1199-1206, doi:10.1046/j.1365-2427.2003.01093.x.

Covich, A. P., T. A. Crowl, and T. Heartsill-Scalley (2006), Effects of drought and hurricane disturbances on headwater distributions of palaemonid river shrimp (Macrobrachium spp.) in the Luquillo Mountains, Puerto Rico, J. N. Am. Benthol. Soc., 25(1), 99-107, doi:10.1899/ 0887-3593(2006)25[99:EODAHD]2.0.CO;2.

Downs, R. T., and M. Hall-Wallace (2003), The American Mineralogist crystal structure database, Am. Mineral., 88(1), $247-250$.

Eimers, M. C., P. J. Dillon, and S. L. Schiff (2004), Sulphate flux from an upland forested catchment in South-Central Ontario, Canada, Water Air Soil Pollut., 152(1), 3-21, doi:10.1023/b:wate.0000015334.03973.65.

Evans, C., and T. D. Davies (1998), Causes of concentration/discharge hysteresis and its potential as a tool for analysis of episode hydrochemistry, Water Resour. Res., 34(1), 129-137, doi:10.1029/97WR01881.

Gaillardet, J., B. Dupré, P. Louvat, and C. J. Allègre (1999), Global silicate weathering and $\mathrm{CO}_{2}$ consumption rates deduced from the chemistry of large rivers, Chem. Geol., 159(1-4), 3-30, doi:10.1016/S0009-2541(99)00031-5.

Gellis, A. C. (2013), Factors influencing storm-generated suspended-sediment concentrations and loads in four basins of contrasting land use, humid-tropical Puerto Rico, Catena, 104, 39-57, doi:10.1016/j.catena.2012.10.018.

GFDL (2016), Global Warming and Hurricanes: An Overview of Current Research Results, Geophys. Fluid Dyn. Lab./NOAA, GFDL, Princeton Univ. Forrestal Campus, Princton, N. J. [Available at https://www.gfdl.noaa.gov/global-warming-and-hurricanes/.]

Gibbs, R. J. (1967), Amazon River-Environmental factors that control its dissolved and suspended load, Science, 156(3783), $1734-1737$.

Gippel, C. J. (1995), Potential of turbidity monitoring for measuring the transport of suspended solids in streams, Hydrol. Processes, 9(1), 83-97, doi:10.1002/hyp.3360090108.

Godsey, S. E., J. W. Kirchner, and D. W. Clow (2009), Concentration-discharge relationships reflect chemostatic characteristics of US catchments, Hydrol. Processes, 23(13), 1844-1864, doi:10.1002/hyp.7315.

Goldenberg, S. B., C. W. Landsea, A. M. Mestas-Nuñez, and W. M. Gray (2001), The recent increase in Atlantic Hurricane Activity: Causes and implications, Science, 293(5529), 474-479, doi:10.1126/science.1060040.

Grazulis, S., D. Chateigner, R. T. Downs, A. T. Yokochi, M. Quiros, L. Lutterotti, E. Manakova, J. Butkus, P. Moeck, and A. Le Bail (2009), Crystallography Open Database-An open-access collection of crystal structures, J. Appl. Crystallogr., 42, 726-729, doi:10.1107/s0021889809016690.

Gražulis, S., A. Daškevič, A. Merkys, D. Chateigner, L. Lutterotti, M. Quirós, N. R. Serebryanaya, P. Moeck, R. T. Downs, and A. Le Bail (2012), Crystallography Open Database (COD): An open-access collection of crystal structures and platform for world-wide collaboration, Nucleic Acids Res., 40(D1), D420-D427, doi:10.1093/nar/gkr900.

Heartsill-Scalley, T., F. N. Scatena, C. Estrada, W. H. McDowell, and A. E. Lugo (2007), Disturbance and long-term patterns of rainfall and throughfall nutrient fluxes in a subtropical wet forest in Puerto Rico, J. Hydrol., 333(2-4), 472-485, doi:10.1016/j.jhydrol.2006.09.019.

Herndon, E. M., A. L. Dere, P. L. Sullivan, D. Norris, B. Reynolds, and S. L. Brantley (2015), Landscape heterogeneity drives contrasting concentration-discharge relationships in shale headwater catchments, Hydrol. Earth Syst. Sci., 19(8), 3333-3347, doi:10.5194/hess-19-33332015.

Hilton, R. G., A. Galy, N. Hovius, M.-C. Chen, M.-J. Horng, and H. Chen (2008), Tropical-cyclone-driven erosion of the terrestrial biosphere from mountains, Nat. Geosci., 1(11), 759-762, doi:10.1038/ngeo333.

Huntington, T., R. Hooper, and B. Aulenbach (1994), Hydrologic processes controlling sulfate mobility in a small forested watershed, Water Resour. Res., 30(2), 283-295, doi:10.1029/93WR02950.

Inamdar, S., G. Dhillon, S. Singh, T. Parr, and Z. Qin (2015), Particulate nitrogen exports in stream runoff exceed dissolved nitrogen forms during large tropical storms in a temperate, headwater, forested watershed, J. Geophys. Res. Biogeosci., 120, 1548-1566, doi:10.1002/ 2015JG002909.

Intergovernmental Panel on Climate Change (IPCC) (2013), Climate change 2013: The physical science basis, in Contribution of Working Group I to the Fifth Assessment Report of the Intergovernmental Panel on Climage Change, 1535 pp., Cambridge, U. K.

Karmalkar, A. V., R. S. Bradley, and H. F. Diaz (2011), Climate change in Central America and Mexico: Regional climate model validation and climate change projections, Clim. Dyn., 37(3), 605-629, doi:10.1007/s00382-011-1099-9.

Kurtz, A. C., F. Lugolobi, and G. Salvucci (2011), Germanium-silicon as a flow path tracer: Application to the Rio Icacos watershed, Water Resour. Res., 47, W06516, doi:10.1029/2010WR009853. 
Lal, R., J. M. Kimble, and B. A. Stewart (2000), Global Climate Change and Tropical Ecosystems: Advances in Soil Science, CRC Press, Boca Raton, Fla.

Larsen, M. C. (1997), Tropical geomorphology and geomorphic work-A study of geomorphic processes and sediment and water budgets in montane humid-tropical forested and developed watersheds, Puerto Rico, 341 pp., PhD thesis, Univ. of Colorado, Boulder, Colo.

Larsen, M. C. (2000), Analysis of 20th century rainfall and streamflow to characterize drought and water resources in Puerto Rico, Phys. Geogr., 21(6), 494-521.

Larsen, M. C. (2012), Landslides and sediment budgets in four watersheds in eastern Puerto Rico, in Water Quality and Landscape Processes of Four Watersheds in Eastern Puerto Rico, chap. F, U.S. Geol. Surv. Prof. Pap., 1789, edited by S. F. Murphy and R. F. Stallard, pp. 153-178, U.S. Geol. Surv., Reston, Va.

Larsen, M. C., and A. Simon (1993), A rainfall intensity-duration threshold for landslides in a humid-tropical environment, Puerto Rico, Geogr. Ann., Ser. A, 75, 13-23, doi:10.2307/521049.

Ledger, M. E., and A. M. Milner (2015), Extreme events in running waters, Freshwater Biol., 60(12), 2455-2460, doi:10.1111/fwb.12673.

Lewis, J. (1996), Turbidity-controlled suspended sediment sampling for runoff-event load estimation, Water Resour. Res., 32(7), 2299-2310, doi:10.1029/96WR00991.

Lugo, E. A., and T. Heartsill Scalley (2014), Research in the Luquillo experimental forest has advanced understanding of Tropical Forests and resolved management issues, in USDA Forest Service Experimental Forests and Ranges: Research for the Long Term, edited by C. D. Hayes et al., pp. 435-461, Springer, New York.

Lupker, M., C. France-Lanord, J. Lavé, J. Bouchez, V. Galy, F. Métivier, J. Gaillardet, B. Lartiges, and J.-L. Mugnier (2011), A Rouse-based method to integrate the chemical composition of river sediments: Application to the Ganga basin, J. Geophys. Res., 116, F04012, doi:10.1029/ 2010JF001947

MacGillivray, C. W., J. P. Grime, and The Integrated Screening Programme Team (1995), Testing predictions of the resistance and resilience of vegetation subjected to extreme events, Funct. Ecol., 9(4), 640-649, doi:10.2307/2390156.

Malhi, Y. (2012), The productivity, metabolism and carbon cycle of tropical forest vegetation, J. Ecol., 100(1), 65-75, doi:10.1111/j.13652745.2011.01916.x.

Mayer, B., J. B. Shanley, S. W. Bailey, and M. J. Mitchell (2010), Identifying sources of stream water sulfate after a summer drought in the Sleepers River watershed (Vermont, USA) using hydrological, chemical, and isotopic techniques, Appl. Geochem., 25(5), 747-754, doi: 10.1016/j.apgeochem.2010.02.007.

McDowell, W. H. (1998), Internal nutrient fluxes in a Puerto Rican rain forest, J. Trop. Ecol., 14(4), 521-536.

McDowell, W. H., and C. E. Asbury (1994), Export of carbon, nitrogen, and major ions from three tropical montane watersheds, Limnol. Oceanogr., 39(1), 111-125, doi:10.4319/lo.1994.39.1.0111.

McDowell, W. H., and D. Liptzin (2014), Linking soils and streams: Response of soil solution chemistry to simulated hurricane disturbance mirrors stream chemistry following a severe hurricane, For. Ecol. Manage., 332, 56-63, doi:10.1016/j.foreco.2014.06.001.

McDowell, W. H., C. P. McSwiney, and W. B. Bowden (1996), Effects of Hurricane disturbance on groundwater chemistry and Riparian function in a Tropical Rain Forest, Biotropica, 28(4), 577-584, doi:10.2307/2389098.

McDowell, W. H., R. L. Brereton, F. N. Scatena, J. B. Shanley, N. V. Brokaw, and A. E. Lugo (2013), Interactions between lithology and biology drive the long-term response of stream chemistry to major hurricanes in a tropical landscape, Biogeochemistry, 116(1), 175-186, doi: 10.1007/s10533-013-9916-3.

Milliman, J. D., and R. H. Meade (1983), World-wide delivery of river sediment to the oceans, J. Geol., 91, 1-21.

Milliman, J. D., and K. L. Farnsworth (2011), Runoff, erosion, and delivery to the coastal ocean, in River Discharge to the Coastal Ocean: $A$ Global Synthesis, edited by J. D. Milliman and K. L. Farnsworth, pp. 13-69, Cambridge Univ. Press, Cambridge, U. K.

Murphy, S. F., and R. F. Stallard (2012), Hydrology and climate of four watersheds in eastern Puerto Rico, in Water Quality and Landscape Processes of Four Watersheds in Eastern Puerto Rico, chap. C, U.S. Geol. Surv., Prof. Pap., 1789, edited by S. F. Murphy and R. F. Stallard, pp. 43-84, U.S. Geol. Surv., Reston, Va.

Murphy, S. F., R. F. Stallard, M. C. Larsen, and W. A. Gould (2012), Physiography, geology, and land cover of four watersheds in Eastern Puerto Rico, in Water Quality and Landscape Processes of Four Watersheds in Eastern Puerto Rico, chap. A, U.S. Geol. Surv. Prof. Pap., 1789, edited by S. F. Murphy and R. F. Stallard, pp. 3-23, U.S. Geol. Surv., Reston, Va.

Neelin, J. D., C. Chou, and H. Su (2003), Tropical drought regions in global warming and El Niño teleconnections, Geophys. Res. Lett., 30(24), 2275, doi:10.1029/2003GL018625.

NOAA (2015), State of the Climate: Drought for August 2015, NOAA Natl. Cent. for Environ. Inf., published online September 2015. [Available at http://www.ncdc.noaa.gov/sotc/drought/201508.]

NOAA (2016), State of the Climate: Drought for Annual 2015, NOAA Natl. Cent. for Environ. Inf., published online January 2016. [Available at http://www.ncdc.noaa.gov/sotc/drought/201513.]

Ormerod, S. J. (2009), Climate change, river conservation and the adaptation challenge, Aquat. Conserv. Mar. Freshwater Ecosyst., 19(6), 609-613, doi:10.1002/aqc.1062.

Ortiz-Zayas, J. R., W. M. Lewis, J. F. Saunders, J. H. McCutchan, and F. N. Scatena (2005), Metabolism of a tropical rainforest stream, J. N. Am. Benthol. Soc., 24(4), 769-783, doi:10.1899/03-094.1.

Perdrial, N., A. Thompson, P. A. O'Day, C. I. Steefel, and J. Chorover (2014), Mineral transformation controls speciation and pore-fluid transmission of contaminants in waste-weathered Hanford sediments, Geochim. Cosmochim. Acta, 141, 487-507, doi:10.1016/j.gca.2014.06.022.

Perdrial, N., A. Thompson, K. LaSharr, M. K. Amistadi, and J. Chorover (2015), Quantifying particulate and colloidal release of radionuclides in waste-weathered Hanford sediments, J. Environ. Qual., 44(3), 945-952, doi:10.2134/jeq2014.09.0388.

Phillips, C. B., and D. J. Jerolmack (2016), Self-organization of river channels as a critical filter on climate signals, Science, 352(6286), 694697, doi:10.1126/science.aad3348.

Porder, S., A. H. Johnson, H. X. Xing, G. Brocard, S. Goldsmith, and J. Pett-Ridge (2015), Linking geomorphology, weathering and cation availability in the Luquillo Mountains of Puerto Rico, Geoderma, 249-250, 100-110, doi:10.1016/j.geoderma.2015.03.002.

Révész, K., and T. B. Coplen (2008a), Determination of the delta (180/160) of Water: RSIL Lab Code 489, in Chap. C2 of Révész, Kinga, and Coplen, Methods of the Reston Stable Isotope Laboratory, edited by B. Tyler, U.S. Geolo.I Surv. Tech. Methods, 10-C2, 28 p., Reston, Va.

Révész, K., and T. B. Coplen (2008b), Determination of the delta $(2 \mathrm{H} / 1 \mathrm{H})$ of Water: RSIL Lab Code 1574, chap. C1 of Révész, Kinga, and Coplen, Methods of the Reston Stable Isotope Laboratory, edited by B. Tyler, U.S. Geol. Surv. Tech. Methods, 10-C1, 27 p., Reston, Va.

Rietveld, H. (1967), Line profiles of neutron powder-diffraction peaks for structure refinement, Acta Crystallogr., 22(1), 151-152, doi: $10.1107 /$ S0365110X67000234

Rietveld, H. (1969), A profile refinement method for nuclear and magnetic structures, J. Appl. Crystallogr., 2(2), 65-71, doi:10.1107/ S0021889869006558 
Scatena, F. N., and M. C. Larsen (1991), Physical aspects of Hurricane Hugo in Puerto Rico, Biotropica, 23(4), 317-323, doi:10.2307/2388247. Schaefer, D. A., W. H. McDowell, F. N. Scatena, and C. E. Asbury (2000), Effects of hurricane disturbance on stream water concentrations and fluxes in eight tropical forest watersheds of the Luquillo Experimental Forest, Puerto Rico, J. Trop. Ecol., 16(2), 189-207.

Schellekens, J., F. N. Scatena, L. A. Bruijnzeel, A. I. J. M. van Dijk, M. M. A. Groen, and R. J. P. van Hogezand (2004), Stormflow generation in a small rainforest catchment in the Luquillo Experimental Forest, Puerto Rico, Hydrol. Processes, 18(3), 505-530, doi:10.1002/hyp.1335.

Schlesinger, W. H., and E. S. Bernhardt (2013), Biogeochemistry, Academic Press, New York.

Scholl, M. A., and S. F. Murphy (2014), Precipitation isotopes link regional climate patterns to water supply in a tropical mountain forest, eastern Puerto Rico, Water Resour. Res., 50, 4305-4322, doi:10.1002/2013WR014413.

Scholl, M. A., J. B. Shanley, J. P. Zegarra, and T. B. Coplen (2009), The stable isotope amount effect: New insights from NEXRAD echo tops, Luquillo Mountains, Puerto Rico, Water Resour. Res., 45, W12407, doi:10.1029/2008WR007515.

Scholl, M. A., A. Torres-Sanchez, and M. Rosario-Torres (2014), Stable isotope $\left(\delta^{18} \mathrm{O}\right.$ and $\left.\delta^{2} \mathrm{H}\right)$ data for precipitation, stream water, and groundwater in Puerto Rico, U.S. Geol. Surv. Date. [Available at http://criticalzone.org/luquillo/data/dataset/3850/.]

Scholl, M. A., J. B. Shanley, S. F. Murphy, J. K. Willenbring, M. Occhi, and G. González (2015), Stable-isotope and solute-chemistry approaches to flow characterization in a forested tropical watershed, Luquillo Mountains, Puerto Rico, Appl. Geochem., 63, 484-497, doi:10.1016/ j.apgeochem.2015.03.008.

Seiders, V. M. (1971), Geologic map of the El Yunque quadrangle, Puerto Rico, U.S. Geol. Surv. Miscellaneous Invest. Map I-658, U.S. Geol. Surv., Reston, Va. [Available at https://pubs.er.usgs.gov/publication/i658.]

Shanley, J. B., W. H. McDowell, and R. F. Stallard (2011), Long-term patterns and short-term dynamics of stream solutes and suspended sediment in a rapidly weathering tropical watershed, Water Resour. Res., 47, W07515, doi:10.1029/2010WR009788.

Simon, A., M. C. Larsen, and C. R. Hupp (1990), The role of soil processes in determining mechanisms of slope failure and hillslope development in a humid-tropical forest eastern Puerto Rico, Geomorphology, 3(3-4), 263-286, doi:10.1016/0169-555X(90)90007-D.

Smith, A. L., J. H. Schellekens, and A.-L. M. Díaz (1998), Batholiths as markers of tectonic change in the northeastern Caribbean, in Tectonics and Geochemistry of the Northeastern Caribbean, edited by E. G. Lidiak and D. K. Larue, pp. 99-122, Spec. Pap. 322 Geol. Soc. of Am., Boulder, Colo.

Smith, M. D. (2011), An ecological perspective on extreme climatic events: A synthetic definition and framework to guide future research, J. Ecol., 99(3), 656-663, doi:10.1111/j.1365-2745.2011.01798.x.

Stallard, R. F. (2012), Weathering, landscape equilibrium, and carbon in four watersheds in eastern Puerto Rico, in Water Quality and Landscape Processes of Four Watersheds in Wastern Puerto Rico, chap. H, U.S. Geol. Surv. Prof. Pap., 1789, edited by S. F. Murphy and R. F. Stallard, pp. 199-248, U.S. Geol. Surv., Reston, Va.

Stallard, R. F., and J. M. Edmond (1983), Geochemistry of the Amazon: 2. The influence of geology and weathering environment on the dissolved load, J. Geophys. Res., 88(C14), 9671-9688, doi:10.1029/JC088iC14p09671.

Stallard, R. F., and S. F. Murphy (2012), Water quality and mass transport in four watersheds in eastern Puerto Rico, in Water Quality and Landscape Processes of Four Watersheds in Eastern Puerto Rico, chapt. E, U.S. Geol. Surv. Prof. Pap., 1789, edited by S. F. Murphy and R. F. Stallard, pp. 113-152, U.S. Geol. Surv., Reston, Va.

Taylor, M. A., D. B. Enfield, and A. A. Chen (2002), Influence of the tropical Atlantic versus the tropical Pacific on Caribbean rainfall, J. Geophys. Res. Oceans, 107(C9), 3127, doi:10.1029/2001JC001097.

Taylor, M. A., T. S. Stephenson, A. Owino, A. A. Chen, and J. D. Campbell (2011), Tropical gradient influences on Caribbean rainfall, J. Geophys. Res., 116, D00Q08, doi:10.1029/2010JD015580.

USDM (2016), U.S. Drought Monitor Classification Scheme, The Natl. Drought Mitigation Cent., Lincoln, Nebr. [Available at http://droughtmonitor.unl.edu/AboutUs/ClassificationScheme.aspx.]

USDM (2017), United States Drought Monitor: Tabular data Archive, The Natl. Drought Mitigation Cent., Lincoln, Nebr. [Available at http:// droughtmonitor.unl.edu/MapsAndData/DataTables.aspx.]

USGS (2016a), USGS Current Conditions for Puerto Rico: USGS 50065500 Rio Mameyes Nr Sabana, Pr, U.S. Dep. of the Inter./U.S. Geol. Surv. [Available at http://waterdata.usgs.gov/pr/nwis/uv?site_no=50065500.]

USGS (2016b), USGS Current Conditions for Puerto Rico: USGS 50075000 Rio Icacos Nr Naguabo, Pr, U.S. Dep. of the Inter./U.S. Geol. Surv. [Available at http://waterdata.usgs.gov/pr/nwis/uv?site_no $=50075000$.]

USGS (2016c), Drought conditions in Puerto Rico, U.S. Dep. of the Inter./U.S. Geol. Surv. [Available at http://pr.water.usgs.gov/drought/ drought conditions.html.

Walling, D. E., and B. W. Webb (1986), Solutes in river systems, in Solute Processes, edited by S. T. Trudgill, pp. 251-327, John Wiley, Chichester.

White, A. F., A. E. Blum, M. S. Schulz, D. V. Vivit, D. A. Stonestrom, M. Larsen, S. F. Murphy, and D. Eberl (1998), Chemical weathering in a tropical watershed, Luquillo Mountains, Puerto Rico: I. Long-term versus short-term weathering fluxes, Geochim. Cosmochim. Acta, 62(2), 209-226, doi:10.1016/S0016-7037(97)00335-9.

Zou, X., C. P. Zucca, R. B. Waide, and W. H. McDowell (1995), Long-term influence of deforestation on tree species composition and litter dynamics of a tropical rain forest in Puerto Rico, For. Ecol. Manage., 78(1), 147-157, doi:10.1016/0378-1127(95)03586-9. 